\title{
Comparison of total water vapor column from GOME-2 on MetOp-A against ground-based GPS measurements at the Iberian Peninsula
}

\author{
R. Román ${ }^{\mathrm{a}, *}$, M. Antón ${ }^{\mathrm{b}}$, V.E. Cachorro a , D. Loyola ${ }^{\mathrm{c}}$, J.P. Ortiz de Galisteo ${ }^{\mathrm{a}, \mathrm{d}}$, \\ A. de Frutos ${ }^{\text {a }}$, P.M. Romero-Campos ${ }^{\mathrm{e}}$ \\ a Grupo de Óptica Atmosférica (GOA), Universidad de Valladolid, Valladolid, Spain \\ b Departamento de Física, Universidad de Extremadura, Badajoz, Spain \\ ${ }^{c}$ Remote Sensing Technology Institute (IMF), German Aerospace Center (DLR), Oberpfaffenhofen, Germany \\ ${ }^{d}$ Meteorological State Agency (AEMET), Regional Office in Castilla y León, Spain \\ e Izaña Atmospheric Research Center (IARC), Meteorological State Agency (AEMET), Spain
}

\section{H I G H L I G H T S}

- Water vapor from GOME-2 is compared against GPS measurements at Iberian Peninsula.

- Mean Bias Error of GOME-2/GPS increases when cloud fraction decreases.

- Mean Bias Error of GOME-2/GPS increases when solar zenith angle increases.
GRA P H I C A L A B S T R A C T

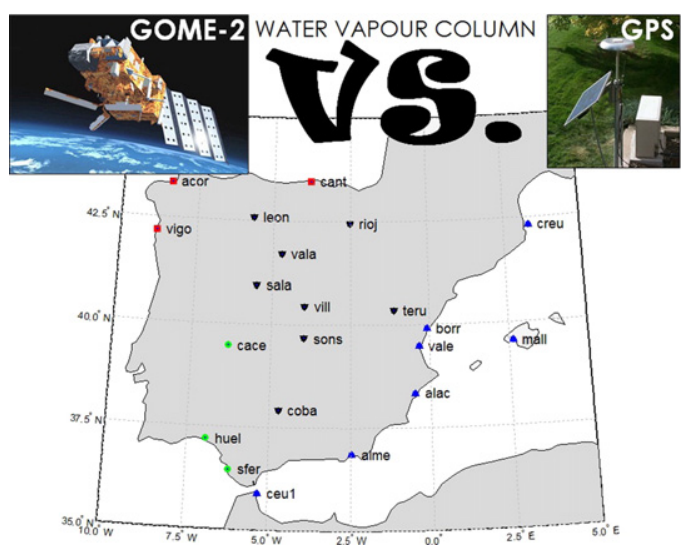

\begin{abstract}
A B S T R A C T
Water vapor column (WVC) obtained by GOME-2 instrument (GDP-4.6 version) onboard MetOp-A satellite platform is compared against reference WVC values derived from GPS (Global Positioning System) instruments from 2007 to 2012 at 21 places located at Iberian Peninsula. The accuracy and precision of GOME-2 to estimate the WVC is studied for different Iberian Peninsula zones using the mean (MBE) and the standard deviation (SD) of the GOME-2 and GPS differences. A direct comparison of all available data shows an overestimation of GOME-2 compared to GPS with a MBE of $0.7 \mathrm{~mm}(10 \%)$ and a precision quantified by a SD equals to $4.4 \mathrm{~mm}$ (31\%). South-Western zone presents the highest overestimation with a MBE of $1.9 \mathrm{~mm}$ (17\%), while Continental zone shows the lowest SD absolute value $(3.3 \mathrm{~mm}$ ) due mainly to the low WVC values reached at this zone. The influence of solar zenith angle (SZA), cloud fraction (CF), and the type of surface and its albedo on the differences between GOME-2 and GPS is analyzed in detail. MBE and SD increase when SZA increases, but MBE decreases (taking negative values) when CF increases and SD shows no significant dependence on CF. Under cloud-free conditions, the differences between WVC from GOME-2 and GPS are within the WVC error given by GOME-2.
\end{abstract}

\footnotetext{
* Corresponding author.

E-mail address: robertor@goa.uva.es (R. Román).
} 
MetOp-A,

Iberian Peninsula
The changes of MBE and SD on Surface Albedo are not so evident, but MBE slightly decreases when the Surface Albedo increases. WVC from GOME-2 is, in general, more precise for land than for sea pixels.

\section{Introduction}

Water vapor is a greenhouse gas mainly located in the lower troposphere which presents an infrared absorption accounting for about $60 \%$ of the natural greenhouse effect for cloud-free skies (Kiehl and Trenberth, 1997). Additionally, it provides latent heating caused by the water vapor condensation; water vapor represents a positive climate feedback according to general circulation models (Colman 2003; Soden and Held, 2006). All this makes that water vapor plays a key role in the climate change, atmospheric temperature and heating exchange and transfer (IPCC, 2013).

In order to quantify the amount of water vapor in the atmosphere, the content of the water vapor column (WVC) is expressed as the height $(\mathrm{mm})$ that would reach the water if all of the water vapor contained in a vertical column of unit horizontal cross section were condensed into liquid. WVC can be measured by different techniques like radiosounding from weather balloons equipped with pressure, temperature and humidity sensors (e.g., Ross and Elliott, 2001; McMillin et al., 2007; Durre et al., 2009), and radiometry from radiative measurements in the absorption spectral bands of water vapor using spectrometers, microwave radiometers and sun photometers (e.g., Cachorro et al., 1987; 1998; Livingston et al., 2007; Schneider et al., 2010; Pérez-Ramírez et al., 2014).

Furthermore, WVC values are also derived from ground-based GPS (Global Positioning System) receivers, since atmospheric water vapor causes a delay in the GPS satellites signal (Hogg et al., 1981; Resch, 1984). WVC can be retrieved from the so called Zenith Total Delay (ZTD) of GPS signal, which is determined from actual measurements of GPS receivers (Herring et al., 1990; Tralli and Lichten, 1990; Duan et al., 1996). The quality of the WVC data from GPS receivers has been evaluated by means of comparisons with different instruments and techniques, reporting root mean square errors between 1 and $3 \mathrm{~mm}$ (Ortiz de Galisteo et al., 2014).

Several instruments on board satellite platforms can also retrieve WVC values. Among others: MODIS on board Terra and Aqua satellites (Kaufman and Gao, 1992), SSMIS on board F16 satellite (Wentz, 2013), MERIS (Lindstrot et al., 2012) and SCIAMACHY (Bovensmann et al., 1999; Mieruch et al., 2006) on board Envisat satellite, GOME on board ERS-2 satellite (Burrows et al., 1999; Noël et al., 2006), and GOME-2 on board MetOp-A and MetOp-B satellites (Munro et al., 2006; Noël et al., 2008; Grossi et al., 2015). These satellite instruments provide a full spatial coverage, allowing a global analysis of the WVC values. Nevertheless, the satellite WVC observations must be inter-compared against reliable measurements in order to assure their quality. For this goal, WVC data from GPS instruments have proved to be an excellent reference (e.g., Baker et al., 2001; Li et al., 2003; Mears et al., 2015).

In this framework, the main objective of this work is to carry out a detailed validation of the GOME-2 WVC data using GPS measurements at the Iberian Peninsula. Although WVC data derived from GOME-2 have been already validated against diverse techniques (e.g., Kalakoski et al., 2011, 2014; Grossi et al., 2013, 2015; Antón et al., 2015), this study should be considered as complementary since the satellite and ground-based measurements are compared under different conditions in order to quantify the effect of several factors affecting the accuracy and precision of the GOME-2 retrieval.

The study region is focused on the Iberian Peninsula which presents several climatological scenarios (e.g., Mediterranean, Atlantic and Continental climates). Hence a satellite validation in this area can be useful to see the behavior of satellite product against different conditions. Some authors studied and remarked the importance of water vapor at the Iberian Peninsula comparing different techniques (Torres et al., 2010; Ortiz de Galisteo et al., 2011, 2014). In addition, Bennouna et al. (2013) and Román et al. (2014b) compared WVC inferred by MODIS instrument at different places located in the Iberian Peninsula. However, to our knowledge, the validation of GOME-2 WVC at Iberian Peninsula has not been performed yet.

This paper is structured as follows: Section 2 presents a detailed description of the satellite and ground-based data used in this work. The applied methodology to select the measurements together with the indices used to analyze the accuracy and precision of GOME-2 WVC data are explained in detail in Section 3. Section 4 shows the detailed comparison between satellite and ground-based WVC data under different conditions. Finally, the main conclusions are summarized in Section 5.

\section{Instrumentation and data}

\subsection{Satellite observations}

GOME-2 is an improved version of the GOME instrument, being a medium-resolution double UV-VIS-NIR spectrometer. The primary product of the GOME-2 mission is the total atmospheric content of ozone and the vertical ozone profile, but it also provides accurate information on the total column amount of water vapor, sulfur dioxide, total and tropospheric nitrogen dioxide, bromine oxide and other trace gases, as well as aerosols and cloud properties. Its default swath width of the scan is $1920 \mathrm{~km}$ which enables global coverage of the Earth's surface within 1.5 days and a maximum ground pixel resolution (across track $\times$ along track) of $80 \mathrm{~km} \times 40 \mathrm{~km}$ (EUMETSAT, 2011). The WVC data used in this work were derived from the GOME Data Processor (GDP, versions 4.6) generated by the German Aerospace Center, Remote Sensing Technology Institute (DLR-IMF) in the framework of the EUMETSAT Satellite Application Facility on Atmospheric Chemistry Monitoring (O3M SAF) (Valks et al., 2011).

The WVC retrieval implemented in GDP is based on the classical DOAS (Differential Optical Absorption) fitting algorithm using the wavelength region of 614-683 $\mathrm{nm}$ followed by non-linearity absorption correction and finally the calculation of the vertical column density using an air mass factor derived from the measured $\mathrm{O}_{2}$ absorption. For more details see (Grossi et al., 2015) and references herein.

Besides WVC, the following GOME-2 parameters provided in the HDF5 products were also used in this study: "SolarZenithAngleCentre" which is the SZA at the surface for the pixel center; "CloudFraction" which is the cloud fraction (CF) ranging from 0 to 1 ; "SurfaceAlbedo" which is the climatological Surface Albedo (SA) used for cloud retrieval; "SurfaceConditionFlags" is an Albedo Flag (AF) for different pixel retrieval conditions, being equal to 1 when at least $60 \%$ of the ground pixel's area is classified as "sea" and equal to 0 for "land" (other flags are for subpixels affected by sun-glint or ice/snow presence); "H2O_Flag” is a flag indexing WVC observations (different to 0 for measurement in cloudy and/or elevation conditions); "H2O_Error" which is the retrieval error $(\varepsilon)$ of the WVC observations.

According to Loyola et al. (2012), the expected accuracy and precision of GOME-2 WVC products are between $10-25 \%$ and 5-20\%, respectively; while the expected accuracy and precision of $\mathrm{CF}$ is below $10 \%$.

\subsection{GPS data}

The WVC data used as reference in this work were retrieved following the method described by Bevis et al. (1992), who quantified the 


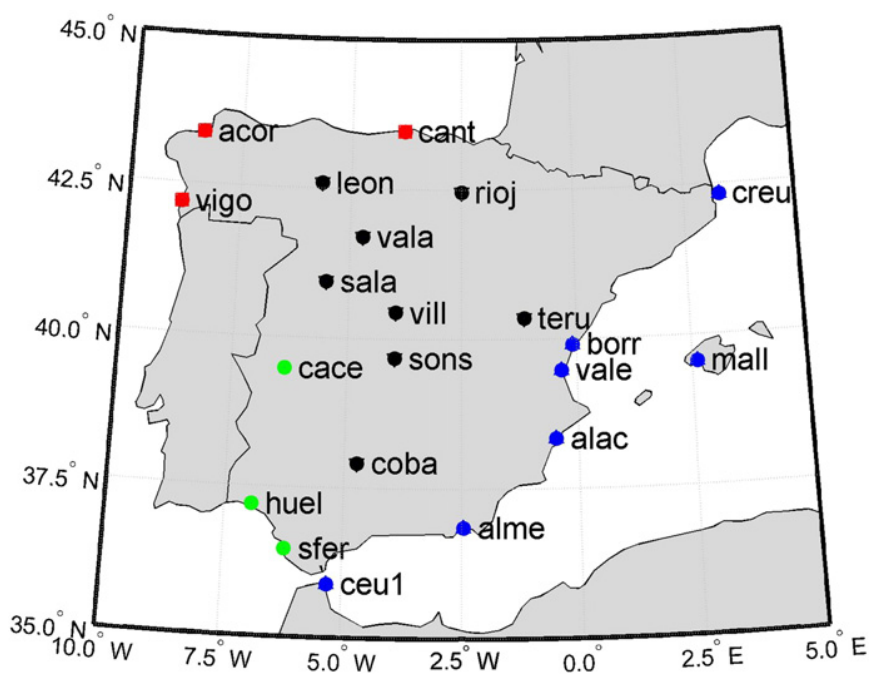

Fig. 1. Ground-based GPS stations marked in a map of Spain. Places in red are for North Atlantic (NA) region, in black for Continental (C) region, in blue for Mediterranean (M) region, and in green for South-Western (SW) region.

uncertainty of this WVC in $0.2 \mathrm{~mm}$. This method relies on ZTD measurements recorded by GPS receivers at 21 ground-based stations located in Spain (Fig. 1); these GPS data are processed by the Spanish Geographic Institute "Instituto Geográfico Nacional" (IGN), which belongs to the European Reference Frame (EUREF) as local analysis center. In addition, pressure and temperature data are required, which were obtained from the nearest available meteorological station of the Spanish Meteorological State Agency (AEMET). These temperature and pressure data were interpolated to the time of ZTD measurements (Ortiz de Galisteo, 2014). The temperature was linearly interpolated while the pressure was interpolated taking into account the barometric tide, which over Spain presents a semi-diurnal cycle with maximum values around 10:00 and 22:00 UTC, the minimum around 04:00 and 16:00 UTC, and a mean amplitude of $0.5 \mathrm{hPa}$ (Ray and Ponte, 2003). Additionally, a correction based on the altitude difference between GPS and meteorological stations was applied to the data considering a standard atmosphere with a temperature vertical gradient of $6.5^{\circ} \mathrm{C} \mathrm{km}^{-1}$. Finally, hourly
WVC data at the 21 GPS stations were available for this work, considering the period from 2007 to 2012.

The selected ground-based stations are classified in different zones: North-Atlantic (NA), Continental (C), Mediterranean (M), and SouthWestern (SW). This classification is based on the previous study of Bennouna et al. (2013). The stations of Ceuta (ceu1) and Mallorca (mall) are not properly in the Iberian Peninsula, but they were also used due to their proximity to the Iberian Peninsula and their Mediterranean conditions.

\section{Methodology}

\subsection{Inter-comparison criteria}

The spatial co-location criterion followed in this paper to select GOME-2 WVC data was to work with those satellite observations in which the distance $(\Delta r)$ between the center of the satellite pixel and the ground-based GPS station was the lowest, and always less than $100 \mathrm{~km}$.

The comparison with GPS data near the coast is based on GOME-2 data covering mixed land/ocean area and the comparison with remaining data just with land area; therefore the measurements affected by sun-glint were removed in order to study the effect only of land and sea classified pixels. Once the GOME-2 data were obtained at each station (within $100 \mathrm{~km}$ of distance and rejecting sun-glint data), the WVC data (but not the other parameters from GOME-2 products) under an "H2O_Flag" above zero (heavy cloudy conditions) were rejected. Table 1 shows the number of GOME-2 measurements selected in each location from 2007 to $2012(\sim 1600)$ before the rejection of "H2O_Flag" above 0; however, the final number of available WVC data ("H2O_flag" equal to 0) is always smaller than $1400(\sim 75 \%$ of all GOME-2 data). Regarding the temporal criterion followed in this work to compare GOME-2 and GPS WVC values, the hourly data of GPS closest to the overpass satellite time (usually between 08:30 and 11.30 UTC) were selected every day at each station. Nevertheless, if the temporal difference between GOME-2 overpass and the selected GPS measurement in a day was higher than 30 min because GPS data is missing, this day was removed from the inter-comparison. Table 2 displays the number of pairs of GOME-2/GPS data used in the inter-comparison for each ground-based station applying the spatial and temporal co-location criteria, in addition to the "H2O_flag" criterion.

Table 1

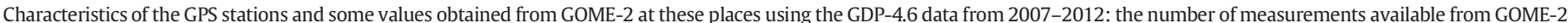

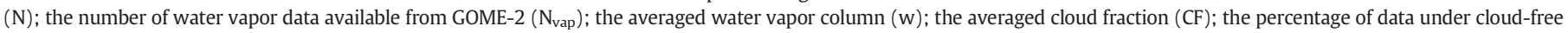

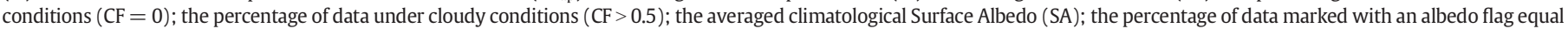
to zero $(\mathrm{AF}=0)$ and the percentage of data marked with an albedo flag equal to one $(\mathrm{AF}=1)$.

\begin{tabular}{|c|c|c|c|c|c|c|c|c|c|c|c|c|c|}
\hline Station & Acronym & Zone & Latitude $\left(+\mathrm{N}^{\circ}\right)$ & Longitude $\left(+\mathrm{E}^{\circ}\right)$ & $\mathrm{N}$ & $\mathrm{N}_{\mathrm{vap}}$ & $\mathrm{w}(\mathrm{mm})$ & $\mathrm{CF}$ & $\mathrm{CF}=0(\%)$ & $\mathrm{CF}>0.5(\%)$ & SA & $\mathrm{AF}=0(\%)$ & $\mathrm{AF}=1(\%)$ \\
\hline A Coruña & acor & NA & 43.36 & -8.40 & 1675 & 1358 & 18.36 & 0.39 & 14.4 & 37.9 & 0.09 & 73.1 & 26.9 \\
\hline Santander & cant & NA & 43.47 & -3.80 & 1676 & 1264 & 18.67 & 0.44 & 13.4 & 44.8 & 0.04 & 54.7 & 45.3 \\
\hline Vigo & vigo & NA & 42.18 & -8.81 & 1675 & 1347 & 18.75 & 0.32 & 20.1 & 29.3 & 0.11 & 78.1 & 21.9 \\
\hline Córdoba & coba & $\mathrm{C}$ & 37.92 & -4.72 & 1559 & 1349 & 16.34 & 0.22 & 36.1 & 19.8 & 0.19 & 100 & 0 \\
\hline León & leon & C & 42.59 & -5.65 & 1675 & 1353 & 13.28 & 0.31 & 27.2 & 30.1 & 0.21 & 100 & 0 \\
\hline Logroño & rioj & $\mathrm{C}$ & 42.46 & -2.50 & 1669 & 1321 & 14.95 & 0.38 & 19.8 & 38.5 & 0.21 & 100 & 0 \\
\hline Salamanca & sala & C & 40.95 & -5.50 & 1674 & 1363 & 13.39 & 0.24 & 41.0 & 22.3 & 0.20 & 100 & 0 \\
\hline Sonseca & sons & C & 39.68 & -3.96 & 1610 & 1368 & 14.22 & 0.21 & 35.8 & 18.1 & 0.20 & 100 & 0 \\
\hline Teruel & teru & C & 40.35 & -1.12 & 1595 & 1230 & 12.84 & 0.26 & 35.7 & 23.6 & 0.14 & 99.7 & 0.3 \\
\hline Valladolid & vala & C & 41.70 & -4.71 & 1654 & 1343 & 13.3 & 0.25 & 32.0 & 23.0 & 0.20 & 100 & 0 \\
\hline Villafranca & vill & C & 40.44 & -3.95 & 1670 & 1398 & 13.5 & 0.23 & 36.9 & 20.7 & 0.20 & 100 & 0 \\
\hline Alicante & alac & M & 38.34 & -0.48 & 1498 & 1231 & 18.11 & 0.22 & 25.4 & 19.3 & 0.08 & 66.5 & 33.5 \\
\hline Almería & alme & M & 36.85 & -2.46 & 1508 & 1241 & 17.73 & 0.19 & 37.3 & 16.4 & 0.05 & 88.5 & 11.5 \\
\hline Burriana & borr & M & 39.91 & -0.08 & 1569 & 1189 & 18.22 & 0.24 & 28.6 & 22.4 & 0.08 & 50.6 & 49.4 \\
\hline Ceuta & ceu1 & M & 35.89 & -5.31 & 1484 & 1263 & 21.5 & 0.26 & 22.3 & 23.0 & 0.03 & 48.6 & 51.4 \\
\hline Creus & creu & M & 42.32 & 3.32 & 1651 & 1233 & 20.91 & 0.27 & 25.9 & 24.6 & 0.06 & 60.7 & 39.3 \\
\hline Mallorca & mall & M & 39.55 & 2.63 & 1539 & 1165 & 23.18 & 0.24 & 25.8 & 20.7 & 0.02 & 54.6 & 45.4 \\
\hline Valencia & vale & M & 39.48 & -0.34 & 1569 & 1231 & 18.4 & 0.24 & 26.0 & 22.1 & 0.08 & 58.8 & 41.2 \\
\hline Cáceres & cace & SW & 39.48 & -6.34 & 1619 & 1381 & 17.5 & 0.2 & 49.7 & 18.6 & 0.20 & 100 & 0 \\
\hline Huelva & huel & SW & 37.20 & -6.92 & 1550 & 1354 & 19.28 & 0.18 & 50.5 & 15.6 & 0.12 & 97.9 & 2.1 \\
\hline San Fernando & sfer & SW & 36.46 & -6.21 & 1520 & 1320 & 19.96 & 0.2 & 36.2 & 16.6 & 0.04 & 76.4 & 23.6 \\
\hline
\end{tabular}




\section{Table 2}

Statistical estimators of the direct comparison of water vapor column from GOME-2 versus GPS at different stations: number of data used $(\mathrm{N})$; y-intercept $\left(\mathrm{y}_{0}\right)$, slope (b) and correlation coefficient $(r)$ of the linear fit; Mean Bias Error $\left(M_{B} E_{s}\right)$; standard deviation of the GOME-2 minus GPS distribution ( $\mathrm{SD}_{\mathrm{s}}$ ) in $\mathrm{mm}$ and \%; the percentage of GOME-2 minus GPS differences lower than the GOME-2 error $v\left(\Delta_{\mathrm{s}}<\varepsilon\right)$ and lower than twice the GOME-2 error $v\left(\Delta_{\mathrm{s}}<2 \varepsilon\right)$.

\begin{tabular}{|c|c|c|c|c|c|c|c|c|c|c|}
\hline Station & $\mathrm{N}$ & $\begin{array}{l}\mathrm{y}_{0} \\
(\mathrm{~mm})\end{array}$ & b & $r$ & $\begin{array}{l}\mathrm{MBE}_{\mathrm{s}} \\
(\mathrm{mm})\end{array}$ & $\begin{array}{l}\mathrm{MBE}_{\mathrm{S}} \\
(\%)\end{array}$ & $\begin{array}{l}\mathrm{SD}_{\mathrm{s}} \\
(\mathrm{mm})\end{array}$ & $\begin{array}{l}\mathrm{SD}_{\mathrm{s}} \\
(\%)\end{array}$ & $\begin{array}{l}v\left(\Delta_{\mathrm{S}}<\varepsilon\right) \\
(\%)\end{array}$ & $\begin{array}{l}v\left(\Delta_{\mathrm{S}}<2 \varepsilon\right) \\
(\%)\end{array}$ \\
\hline acor & 1283 & 1.0 & 0.98 & 0.84 & +0.6 & +5.6 & 4.5 & 29.0 & 54.9 & 86.8 \\
\hline cant & 1244 & 0.2 & 1.03 & 0.84 & +0.7 & +5.4 & 4.9 & 30.3 & 51.5 & 85.7 \\
\hline vigo & 1283 & 2.1 & 0.95 & 0.83 & +1.2 & +9.6 & 4.5 & 28.3 & 55.0 & 88.9 \\
\hline coba & 1321 & 3.2 & 0.73 & 0.81 & -1.7 & -6.6 & 3.9 & 21.7 & 61.6 & 83.3 \\
\hline leon & 1122 & 3.0 & 0.92 & 0.85 & +2.2 & +29.9 & 3.1 & 39.7 & 41.5 & 88.0 \\
\hline rioj & 1258 & 2.2 & 0.84 & 0.84 & -0.3 & +2.8 & 3.9 & 30.4 & 51.5 & 84.2 \\
\hline sala & 1341 & 2.7 & 0.87 & 0.87 & +1.2 & +16.7 & 2.9 & 31.5 & 55.2 & 91.1 \\
\hline sons & 1137 & 3.8 & 0.83 & 0.86 & +1.6 & +22.5 & 3.0 & 34.4 & 48.5 & 87.7 \\
\hline teru & 764 & 2.8 & 0.82 & 0.86 & +0.6 & +13.2 & 3.1 & 38.8 & 61.0 & 91.1 \\
\hline vala & 958 & 2.3 & 0.83 & 0.86 & +0.1 & +5.8 & 3.1 & 26.8 & 60.6 & 90.0 \\
\hline vill & 1343 & 3.1 & 0.75 & 0.85 & -0.4 & +3.4 & 3.4 & 27.6 & 58.2 & 88.5 \\
\hline alac & 1194 & 4.0 & 0.73 & 0.79 & -1.2 & -1.1 & 5.2 & 28.1 & 48.2 & 80.3 \\
\hline alme & 1173 & 3.8 & 0.76 & 0.80 & -0.6 & +0.4 & 4.6 & 25.9 & 59.1 & 86.5 \\
\hline borr & 955 & 3.6 & 0.75 & 0.82 & -1.2 & -1.1 & 5.2 & 29.2 & 53.2 & 80.8 \\
\hline ceu1 & 898 & 3.5 & 0.92 & 0.83 & +2.0 & +13.0 & 4.5 & 25.5 & 53.9 & 92.1 \\
\hline creu & 1035 & 3.4 & 0.95 & 0.86 & +2.5 & +19.3 & 4.6 & 30.0 & 50.4 & 91.6 \\
\hline mall & 1123 & 2.7 & 1.04 & 0.87 & +3.4 & +20.1 & 4.6 & 27.4 & 47.0 & 92.7 \\
\hline vale & 1160 & 4.2 & 0.74 & 0.82 & -0.7 & +2.7 & 5.0 & 28.9 & 54.1 & 84.7 \\
\hline cace & 1272 & 4.5 & 0.85 & 0.81 & +2.2 & +21.7 & 3.9 & 31.8 & 42.8 & 88.7 \\
\hline huel & 1129 & 5.6 & 0.78 & 0.81 & +1.8 & +16.3 & 4.3 & 28.9 & 48.2 & 89.5 \\
\hline sfer & 782 & 4.2 & 0.86 & 0.84 & +1.7 & +13.4 & 3.9 & 23.4 & 52.9 & 93.4 \\
\hline All & 23,775 & 3.0 & 0.86 & 0.84 & +0.7 & +9.9 & 4.4 & 31.1 & 52.7 & 87.7 \\
\hline
\end{tabular}

\subsection{Accuracy and precision indices}

The comparison between the WVC values retrieved by GOME-2 and GPS was carried out using the distribution of differences $\Delta$. The distribution $\Delta_{\mathrm{s}}$ for a given station "s" is formed by $\mathrm{N}_{\mathrm{s}}$ elements, and the i-element of $\Delta_{\mathrm{s}}$ was calculated in physical units by:

$\Delta_{\mathrm{s}, \mathrm{i}}=\mathrm{w}_{\mathrm{s}, \mathrm{i}}^{\mathrm{GOME}}-\mathrm{w}_{\mathrm{s}, \mathrm{i}}^{\mathrm{GPS}}$,

and in a relative way in percentage:

$\Delta_{\mathrm{s}, \mathrm{i}}(\%)=100 \frac{\mathrm{w}_{\mathrm{s}, \mathrm{i}}^{\mathrm{GOME}}-\mathrm{w}_{\mathrm{s}, \mathrm{i}}^{\mathrm{GPS}}}{\mathrm{w}_{\mathrm{s}, \mathrm{i}}^{\mathrm{GPS}}}$,
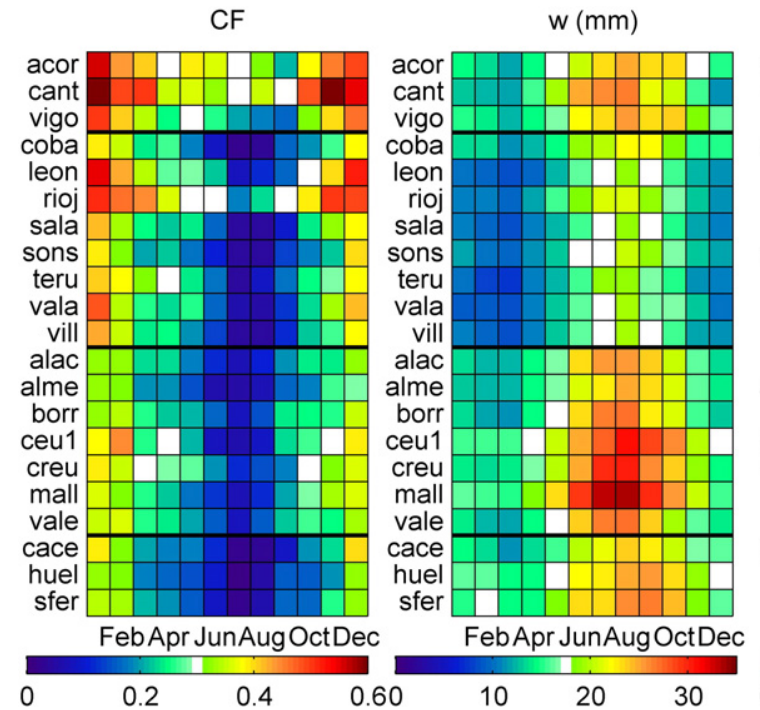

where $\mathrm{w}_{\mathrm{s}, \mathrm{i}}^{\mathrm{GOME}}$ and $\mathrm{w}_{\mathrm{s}, \mathrm{i}}^{\mathrm{GPS}}$ are the WVC for the station "s" at a specific day (fixed by the i-index) obtained by GOME- 2 and GPS, respectively. In order to study the precision and accuracy of the WVC obtained by GOME-2, two statistical indices were applied to the $\Delta_{\mathrm{s}}$ distribution: the Mean Bias Error (MBE), which indicate the accuracy (more accurate when MBE is closer to zero) of GOME-2 to fit within GPS water vapor column measurements; and the standard deviation of $\Delta$ (SD), which is useful to analyze the precision (more precise when SD is lower) of WVC of GOME-2 within the WVC of GPS. MBE and SD for a given station " $\mathrm{s}$ " $\left(\mathrm{MBE}_{\mathrm{s}}\right.$, and $\left.\mathrm{SD}_{\mathrm{s}}\right)$ were calculated using the following equations:

$$
\begin{aligned}
& \mathrm{MBE}_{\mathrm{s}}=\frac{1}{\mathrm{~N}_{\mathrm{s}}} \sum_{\mathrm{i}=1}^{\mathrm{N}_{\mathrm{s}}} \Delta_{\mathrm{s}, \mathrm{i}}, \\
& \mathrm{SD}_{\mathrm{s}}=\sqrt{\frac{1}{\mathrm{~N}_{\mathrm{s}}-1} \sum_{\mathrm{i}=1}^{\mathrm{N}_{\mathrm{s}}}\left(\Delta_{\mathrm{s}, \mathrm{i}}-\mathrm{MBE}_{\mathrm{s}}\right)^{2},}
\end{aligned}
$$

where $\mathrm{N}_{\mathrm{S}}$ is the number of pairs of WVC data (GOME-2 and GPS) available at the station "s", and $\Delta_{s}$ is the distribution of differences between GOME- 2 and GPS for the station "s". $\mathrm{MBE}_{\mathrm{s}}$ and $\mathrm{SD}_{\mathrm{s}}$ can be calculated in physical or relative units depending on whether $\Delta_{S}$ is calculated by Eq. (1) or Eq. (2).

In order to obtain a representative value of $\mathrm{MBE}$ and $\mathrm{SD}$ for a given zone " $\mathrm{z}$ " $\left(\mathrm{MBE}_{\mathrm{z}}\right.$ and $\left.\mathrm{SD}_{\mathrm{z}}\right)$ represented by various stations, the values of $\mathrm{MBE}_{\mathrm{s}}$ and $\mathrm{SD}_{\mathrm{s}}$ were averaged for the different stations of the zone " $\mathrm{z}$ " using the next equations:

$$
\begin{aligned}
& \mathrm{MBE}_{\mathrm{z}}=\frac{1}{\mathrm{~N}_{\text {sta }}} \sum_{s=1}^{\mathrm{N}_{\mathrm{sta}}} \mathrm{MBE}_{\mathrm{s}}, \\
& \mathrm{SD}_{\mathrm{z}}=\frac{1}{\mathrm{~N}_{\mathrm{sta}}} \sum_{\mathrm{s}=1}^{\mathrm{N}_{\text {sta }}} \mathrm{SD}_{\mathrm{s}},
\end{aligned}
$$

where $\mathrm{N}_{\mathrm{sta}}$ is the number of stations used to obtain the value of $\mathrm{MBE}_{\mathrm{z}}$ and $\mathrm{SD}_{\mathrm{z}}$ in the zone " $\mathrm{z}$ "; if a $\mathrm{MBE}_{\mathrm{s}}$ or $\mathrm{SD}_{\mathrm{s}}$ value was calculated with less than 10 measurement pairs, then it was not used to obtain $\mathrm{MBE}_{z}$ or $\mathrm{SD}_{\mathrm{z}}$. This method to calculate MBE and SD in a zone "z" was chosen in order to give the same weight to each station in the calculated zone, independently on the number of data of each station. Finally, in order to quantify the variation of $\mathrm{MBE}_{\mathrm{z}}$ and $\mathrm{SD}_{\mathrm{z}}$ within the calculated

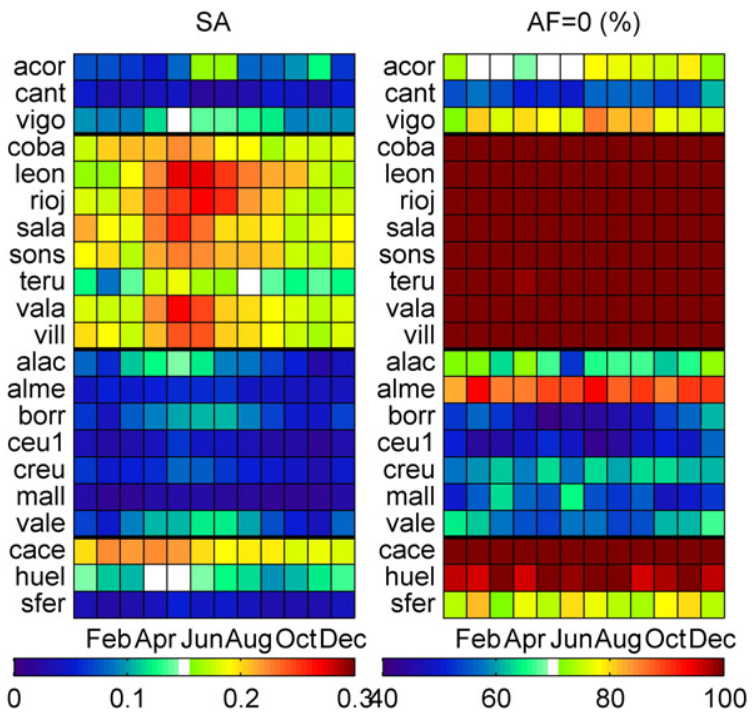

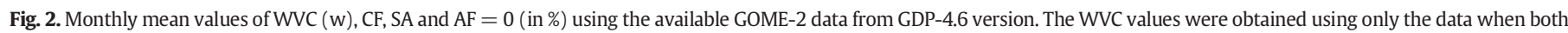
GOME-2 and GPS data were available. 
zone, the standard deviation of these coefficients $\left(\operatorname{std}\left(\mathrm{MBE}_{\mathrm{z}}\right)\right.$ and $\left.\operatorname{std}\left(\mathrm{SD}_{z}\right)\right)$ were calculated as follows:

$\operatorname{std}\left(\mathrm{MBE}_{\mathrm{z}}\right)=\sqrt{\frac{1}{\mathrm{~N}_{\mathrm{sta}}-1} \sum_{\mathrm{s}=1}^{\mathrm{N}_{\mathrm{sta}}}\left(\mathrm{MBE}_{\mathrm{s}}-\mathrm{MBE}_{\mathrm{z}}\right)^{2}}$,

$\operatorname{std}\left(\mathrm{SD}_{\mathrm{z}}\right)=\sqrt{\frac{1}{\mathrm{~N}_{\mathrm{sta}}-1} \sum_{\mathrm{s}=1}^{\mathrm{N}_{\mathrm{sta}}}\left(\mathrm{SD}_{\mathrm{s}}-\mathrm{SD}_{\mathrm{z}}\right)^{2}}$.

The accuracy and precision of WVC obtained by GOME-2 in a given zone " $\mathrm{z}$ " formed by $\mathrm{N}_{\text {sta }}$ "s" stations, and their variation in this zone, are well quantified by the explained indices and their standard deviations. Note that SD and std() are both calculated as standard deviation but their meaning is different; SD represents the precision of GOME-2 to obtain WVC, and the $\operatorname{std}(\mathrm{SD})$ means how this precision varies in a zone (in the case of std(MBE) it means how the accuracy varies). To simplify, when $\mathrm{MBE}_{\mathrm{z}}$ and $\mathrm{SD}_{\mathrm{z}}$ are obtained for the zone "all" (taking all available stations), the " $\mathrm{z}$ " sub-index is removed.

Other indices used to quantify the agreement between GOME-2 and GPS data were the slope (b), y-intercept ( $\left.\mathrm{y}_{0}\right)$ and correlation coefficient ( $r$ ) of the linear Least-Squares fit between GOME-2 as a function of GPS data. Finally, the error, $\varepsilon$, of a measurement, $X$, usually indicates that the probability of finding the true value of the measured variable within the confidence interval $(X-\varepsilon, X+\varepsilon)$ is $68 \%$, while this probability is $95 \%$ for the confidence interval ( $X-2 \varepsilon, X+2 \varepsilon$ ) (Román et al., 2014a); therefore, the frequency of the difference $\Delta_{\mathrm{s}}$ lower than $\varepsilon, v\left(\Delta_{\mathrm{S}}<\varepsilon\right)$, and $2 \varepsilon, v\left(\Delta_{S}<2 \varepsilon\right)$, were calculated at each station. If the differences between GOME-2 and GPS are within the GOME-2 error, then $v\left(\Delta_{\mathrm{s}}<\varepsilon\right)$ and $v\left(\Delta_{\mathrm{S}}<2 \varepsilon\right)$ should be similar to $68 \%$ and $95 \%$, respectively; hence $v\left(\Delta_{\mathrm{S}}<\varepsilon\right)$ and $v\left(\Delta_{\mathrm{S}}<2 \varepsilon\right)$ were used to estimate if the obtained differences are within the GOME-2 error.

\section{Results and discussion}

\subsection{Analysis of ground-based stations from satellite observations}

All GOME-2 available data were averaged for each ground-based station, and the results are shown in Table 1 . The highest WVC mean values appear at the Mediterranean area with three locations showing a mean value above $20 \mathrm{~mm}$. By contrast, Continental stations present the lowest WVC values, usually the average being below $15 \mathrm{~mm}$. The averaged CF is higher in the NA zone ( $\mathrm{CF}>0.30$ ), in fact the frequency of cloud-free conditions $(C F=0)$ is lower than $20 \%$ while the frequency of cloudy cases $(\mathrm{CF}>0.5)$ is higher than in the others areas. Regarding cloudfree conditions, SW region has the highest values of frequency (around $50 \%$ ), and this frequency is similar for $C$ and $M$ areas (20-40\%). The
Surface Albedo SA in the Continental region is higher than in the remaining areas, showing values around 0.20 and the $\mathrm{AF}$ equal to 0 (land conditions). The climatology SA in the Mediterranean area is below 0.08 and approximately $50 \%$ of data are taken with an $\mathrm{AF}$ equal to 1 .

Fig. 2 shows the monthly means of the mentioned available data of WVC, CF, SA and AF $=0$. The largest WVC values are recorded in summer while the lowest in winter, showing the Mediterranean stations the highest values and Continental stations the lowest ones. These results were also observed in several locations at the Iberian Peninsula by Ortiz de Galisteo et al. (2014), Bennouna et al. (2013), and Román et al. (2014b). The lowest values of CF appear in summer in all zones except in NA region, where CF is similar in summer and spring; the highest $\mathrm{CF}$ values are in winter for all regions; the Continental region shows the highest variation of $\mathrm{CF}$ along the year, with low cloud fraction in summer and high in winter. The monthly variation of Surface Albedo is not high except in Continental region where April, May and June present the highest values, probably due to the variations in the albedo of the crop. Finally, the albedo flag presents no significant changes between months with all Continental places flagged as land, and all Mediterranean locations (except Almería) with more than $30 \%$ of data measured as sea conditions.

\subsection{GOME-2 vs GPS under different conditions}

\subsubsection{All conditions}

Firstly, the GOME-2 WVC data were directly compared with GPS data in each study location using different statistical parameters whose values can be found in Table 2 . The values for the row named "All" were obtained using all available data from all stations together. The slopes closest to 1 appear for NA station with low values of $\mathrm{y}_{0}$, which points out a good agreement in this region. The lowest slopes are in the Mediterranean and Continental areas (being up to 0.73), while the highest values of $\mathrm{y}_{0}$ appear at $\mathrm{SW}$ region. The correlation coefficient $(r)$ of the least square fit is similar for all stations, ranging from 0.80 to 0.87 , which indicates a high correlation between the GOME- 2 and GPS WVC values. $v\left(\Delta_{\mathrm{S}}<\varepsilon\right)$ and $v\left(\Delta_{\mathrm{S}}<2 \varepsilon\right)$ are also included in Table 2, being slightly lower than the expected values; $v\left(\Delta_{s}<\varepsilon\right)$ ranging from $42 \%$ to $62 \%$ and $v\left(\Delta_{\mathrm{s}}<2 \varepsilon\right)$ from $80 \%$ to $93 \%$. This result indicates that a non-negligible percentage of the differences between GOME-2 and GPS cannot be explained by the expected uncertainties inherent to the GDP retrieval.

The values of $\mathrm{MBE}_{\mathrm{s}}$ and $\mathrm{SD}_{\mathrm{s}}$ calculated using Eq. (3) are also included in Table 2 both in $\mathrm{mm}$ as well as in percentage. The absolute MBE is positive (indicating that GOME-2 overestimates the GPS measurements), except in three and four stations at Continental and Mediterranean areas, respectively. $\mathrm{MBE}_{\mathrm{s}}$ is lower than $+10 \%$ for NA area; the

Table 3

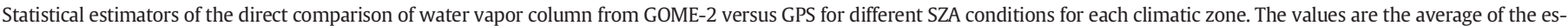
timators at the $\mathrm{N}_{\text {sta }}$ stations used in each zone, and the standard deviation of these averaged values is given in parentheses.

\begin{tabular}{|c|c|c|c|c|c|c|c|c|c|}
\hline Zone & SZA condition & $\mathrm{N}$ & $\mathrm{N}_{\text {sta }}$ & $\mathrm{MBE}_{\mathrm{z}}(\mathrm{mm})$ & $\mathrm{MBE}_{\mathrm{z}}(\%)$ & $\mathrm{SD}_{\mathrm{z}}(\mathrm{mm})$ & $\mathrm{SD}_{\mathrm{z}}(\%)$ & $\overline{v_{z}\left(\Delta_{s}<\varepsilon\right)}(\%)$ & $\overline{v_{z}\left(\Delta_{s}<2 \varepsilon\right)}(\%)$ \\
\hline NA & $\mathrm{SZA} \leq 40^{\circ}$ & 1406 & 3 & $-0.1(0.7)$ & $-0.1(3.5)$ & $4.7(0.3)$ & $22.6(0.7)$ & $50.9(2.8)$ & $83.3(1.6)$ \\
\hline NA & $40^{\circ}<\mathrm{SZA} \leq 65^{\circ}$ & 1623 & 3 & $1.2(0.5)$ & $8.5(3.1)$ & $4.6(0.3)$ & $28.6(2.1)$ & $54.2(2.9)$ & $88.8(3.2)$ \\
\hline NA & $\mathrm{SZA}>65^{\circ}$ & 781 & 3 & $1.7(0.7)$ & $16.0(5.3)$ & $4.0(0.0)$ & $36.2(1.2)$ & $58.3(2.4)$ & $90.7(1.6)$ \\
\hline C & $\mathrm{SZA} \leq 40^{\circ}$ & 3335 & 8 & $-1.0(1.2)$ & $-3.5(7.0)$ & $3.4(0.3)$ & $21.0(2.8)$ & $57.4(5.2)$ & $83.7(4.9)$ \\
\hline C & $40^{\circ}<\mathrm{SZA} \leq 65^{\circ}$ & 4191 & 8 & $0.8(1.2)$ & $12.2(11.4)$ & $3.0(0.5)$ & $27.6(3.9)$ & $56.3(7.4)$ & $90.9(3.8)$ \\
\hline $\mathrm{C}$ & $\mathrm{SZA}>65^{\circ}$ & 1718 & 8 & $2.2(0.9)$ & $34.8(15.8)$ & $2.7(0.4)$ & $38.6(8.8)$ & $46.8(10.6)$ & $90.0(6.0)$ \\
\hline M & $\mathrm{SZA} \leq 40^{\circ}$ & 2810 & 7 & $-0.4(2.8)$ & $0.1(11.9)$ & $4.9(0.4)$ & $20.7(0.7)$ & $49.2(5.1)$ & $82.9(8.4)$ \\
\hline M & $40^{\circ}<\mathrm{SZA} \leq 65^{\circ}$ & 3553 & 7 & $0.7(1.6)$ & $7.7(8.4)$ & $4.6(0.2)$ & $27.3(1.0)$ & $55.1(3.8)$ & $88.2(4.3)$ \\
\hline M & $\mathrm{SZA}>65^{\circ}$ & 1175 & 7 & $2.5(0.5)$ & $23.8(5.1)$ & $4.2(0.4)$ & $34.3(2.7)$ & $51.3(3.8)$ & $92.6(2.3)$ \\
\hline SW & $\mathrm{SZA} \leq 40^{\circ}$ & 1174 & 3 & $1.1(0.4)$ & $8.3(1.8)$ & $3.9(0.2)$ & $21.8(2.4)$ & $54.5(5.2)$ & $88.1(3.2)$ \\
\hline SW & $40^{\circ}<\mathrm{SZA} \leq 65^{\circ}$ & 1574 & 3 & $2.1(0.3)$ & $18.3(3.8)$ & $4.0(0.3)$ & $26.7(2.0)$ & $46.2(3.7)$ & $92.8(0.6)$ \\
\hline SW & $\mathrm{SZA}>65^{\circ}$ & 435 & 3 & $3.4(0.5)$ & $36.4(6.7)$ & $4.0(0.3)$ & $36.4(2.7)$ & $35.5(2.3)$ & $89.6(4.3)$ \\
\hline All & $\mathrm{SZA} \leq 40^{\circ}$ & 8725 & 21 & $-0.4(1.9)$ & $-0.1(9.0)$ & $4.1(0.8)$ & $21.3(2.1)$ & $53.3(6.1)$ & $84.0(6.1)$ \\
\hline All & $40^{\circ}<\mathrm{SZA} \leq 65^{\circ}$ & 10,941 & 21 & $1.0(1.3)$ & $11.1(9.4)$ & $3.9(0.8)$ & $27.5(2.8)$ & $54.2(6.3)$ & $90.0(4.0)$ \\
\hline All & $\mathrm{SZA}>65^{\circ}$ & 4109 & 21 & $2.4(0.9)$ & $28.7(13.0)$ & $3.5(0.8)$ & $36.5(6.1)$ & $48.3(9.5)$ & $90.9(4.5)$ \\
\hline
\end{tabular}




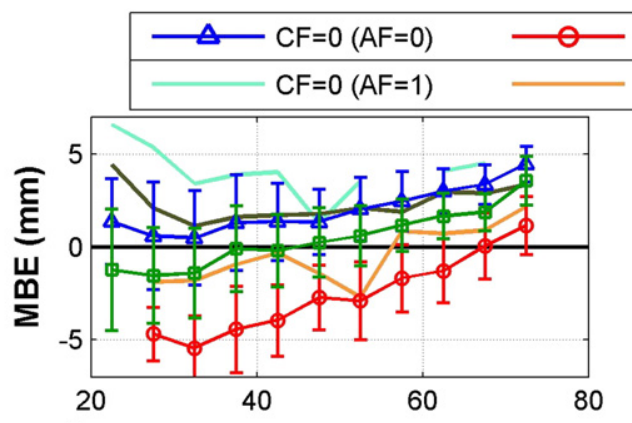

$\mathrm{CF}>0.5(\mathrm{AF}=0) \quad$ - $\mathrm{All}(\mathrm{AF}=0)$
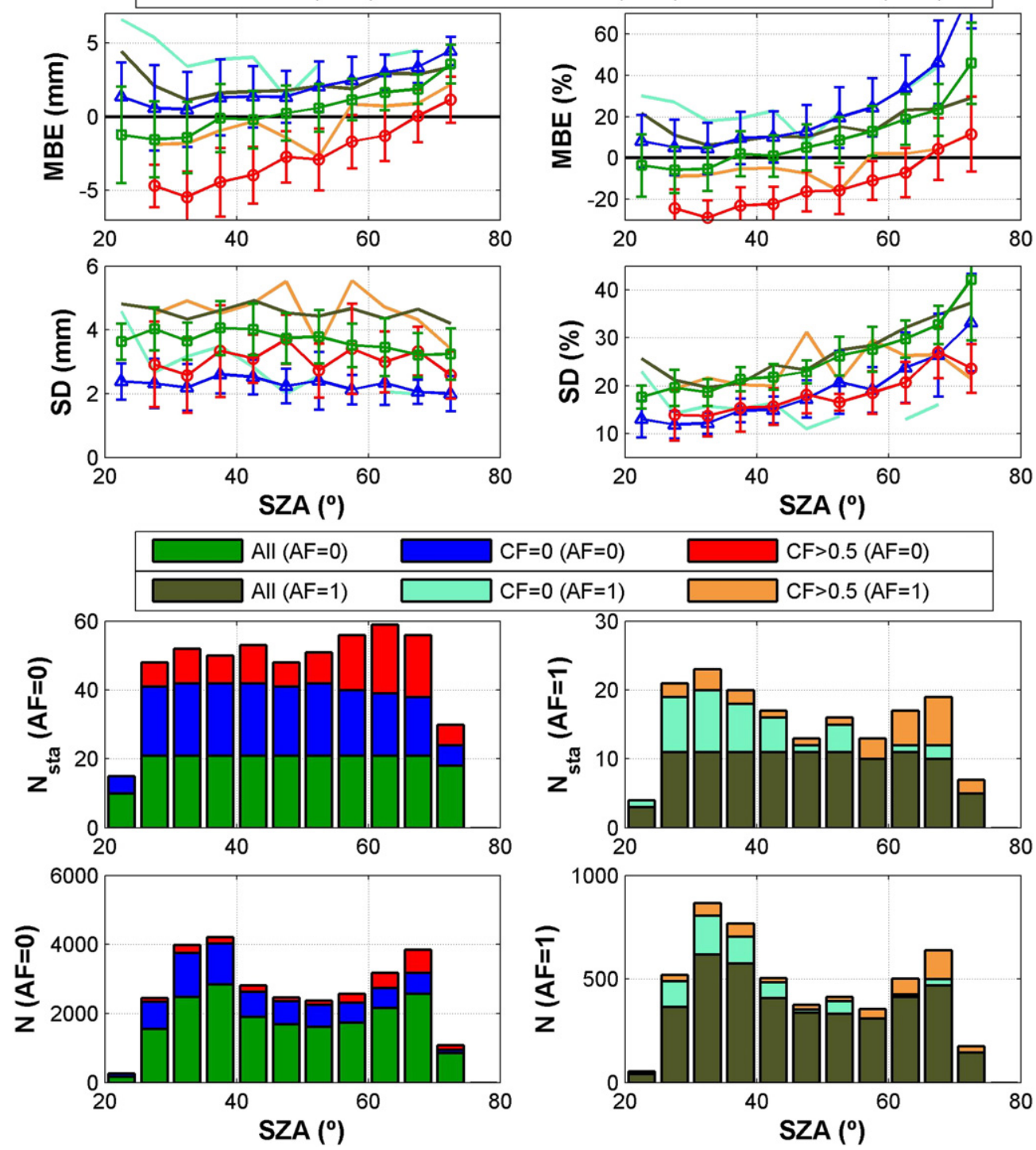

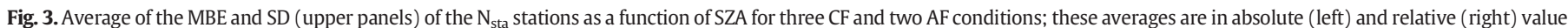

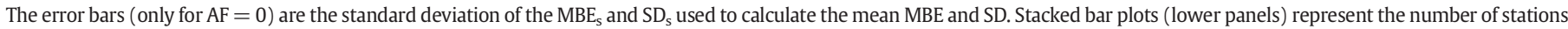

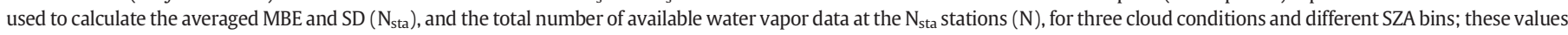
are represented for $\mathrm{AF}=0$ (left) and $\mathrm{AF}=1$ (right).

highest variation of $\mathrm{MBE}_{\mathrm{s}}$ is for Continental area, ranging from -6 to $+30 \%$. Some Mediterranean stations show the highest $\mathrm{MBE}_{\mathrm{s}}$ values with maximum values around $+20 \%$. Regarding $\mathrm{SD}_{\mathrm{s}}$ values, in general Mediterranean stations present the highest precision with $\mathrm{SD}_{\mathrm{s}}$ values from $26-30 \%$, while Continental stations have $\mathrm{SD}_{\mathrm{s}}$ values up to $40 \%$. It indicates that approximately the half of the Mediterranean stations show a great accuracy and precision.

The $\mathrm{MBE}_{\mathrm{s}}$ obtained in this work using all data-stations together was $+0.7 \mathrm{~mm}(+10 \%)$. These results point out better accuracy in the Iberian Peninsula for GOME-2 than for MODIS/Terra instrument (IR algorithm), which presented a MBE equal to $1.0 \mathrm{~mm}$ as reported by Román et al. (2014b). Kalakoski et al. (2014) compared GOME-2 WVC data against GPS data at different worldwide locations, obtaining a MBE of $+15 \%$, substantially higher than the MBE value derived from our analysis.

\subsubsection{SZA dependence}

A notable dependency on SZA of the difference between GOME-2 WVC data and radiosounding measurements has been reported in literature (e.g., Grossi et al., 2013; Kalakoski et al., 2014; Antón et al., 2015). In order to check if this dependency also appears when GPS data are used as reference, $\mathrm{MBE}_{\mathrm{z}}$ and $\mathrm{SD}_{\mathrm{z}}$ were calculated for three SZA intervals averaging the four geographical zones and all stations. Table 3 shows the different statistical parameters calculated for $\mathrm{SZA}<40^{\circ}$, $40^{\circ}<\mathrm{SZA} \leq 65^{\circ}$ and SZA $>65^{\circ}$. The WVC values inferred from GOME-2 at NA, C, and M areas present a great agreement with GPS measurements for SZA below $40^{\circ}$, while this agreement is also reasonably good but with a notable overestimation $\left(\mathrm{MBE}_{\mathrm{z}}=+8.3 \%\right)$ at $\mathrm{SW}$ region.

The precision is similar for all zones at each SZA interval. The accuracy and precision of GOME-2 data worsen when SZA increases, overestimating the GPS data. Overall, the variation of $\mathrm{SD}_{\mathrm{z}}$ inside each zone is low, exhibiting more changes in the Continental area. Regarding the average values in a " $\mathrm{z}$ " zone of $v\left(\Delta_{\mathrm{s}}<\varepsilon\right)\left(\overline{v_{\mathrm{z}}\left(\Delta_{\mathrm{s}}<\varepsilon\right)}\right)$ and $v\left(\Delta_{\mathrm{s}}<2 \varepsilon\right)$ $\left(\overline{v_{z}\left(\Delta_{S}<2 \varepsilon\right)}\right)$, all them present smaller values than the expected, but in most cases $\overline{v_{z}\left(\Delta_{s}<2 \varepsilon\right)}$ is closer to the expected value of $95 \%$. The increase of the relative MBE when increasing SZA was also observed when radiosounding data were used as reference instead of GPS measurements 
Table 4

Absolute and relative differences of the water vapor monthly means (2007-2012) from GOME-2 and GPS averaged by zones.

\begin{tabular}{|c|c|c|c|c|c|c|c|c|c|c|}
\hline \multirow[t]{2}{*}{ Month } & \multicolumn{5}{|c|}{$\Delta \mathrm{M}\left(\mathrm{w}_{\mathrm{m}}\right)(\mathrm{mm})$} & \multicolumn{5}{|c|}{$\Delta \mathrm{M}\left(\mathrm{w}_{\mathrm{m}}\right)(\%)$} \\
\hline & NA & C & M & SW & All & NA & C & M & SW & All \\
\hline Jan & 1.2 & 1.9 & 1.9 & 2.5 & 1.9 & 9.3 & 24.1 & 15.7 & 19.8 & 18.5 \\
\hline Feb & 1.6 & 1.3 & 1.2 & 2.2 & 1.4 & 13.4 & 17.9 & 9.8 & 16.7 & 14.4 \\
\hline Mar & -0.1 & 0.0 & 0.4 & 1.1 & 0.3 & -0.6 & 1.7 & 3.1 & 8.6 & 2.8 \\
\hline Apr. & -0.1 & -0.9 & -0.4 & -0.2 & -0.5 & -0.5 & -6.5 & -2.6 & -1.6 & -3.7 \\
\hline May & -0.9 & -1.7 & -0.5 & -0.4 & -1.0 & -5.0 & -10.6 & -2.8 & -2.1 & -6.0 \\
\hline Jun & 0.3 & -1.1 & 0.2 & 1.5 & -0.1 & 1.3 & -5.5 & 1.4 & 7.6 & -0.4 \\
\hline July & 0.6 & 0.5 & 0.3 & 3.1 & 0.8 & 2.7 & 3.4 & 1.6 & 16.1 & 4.5 \\
\hline Aug & 1.2 & 0.4 & -0.3 & 3.3 & 0.7 & 4.9 & 3.0 & -0.5 & 15.7 & 3.9 \\
\hline Sep & 1.8 & 0.2 & -0.7 & 1.0 & 0.2 & 8.6 & 2.5 & -2.1 & 4.8 & 2.2 \\
\hline Oct & 2.2 & 1.3 & 0.6 & 3.0 & 1.5 & 10.8 & 10.2 & 3.0 & 15.4 & 8.6 \\
\hline Nov & 1.6 & 1.7 & 2.2 & 3.0 & 2.0 & 10.1 & 17.2 & 14.1 & 20.9 & 15.7 \\
\hline Dec & 1.7 & 2.3 & 2.2 & 3.4 & 2.3 & 12.9 & 28.4 & 18.1 & 26.0 & 22.4 \\
\hline
\end{tabular}

(e.g., Grossi et al., 2013; Kalakoski et al., 2014). Antón et al. (2015) suggested that this SZA dependency could be related to inaccuracies in the geometrical correction factor applied in the GOME-2 retrieval algorithm to determine the air mass factor (AMF) of the water vapor.

The SZA dependency of the GOME-2/GPS differences may be also affected by other factors like cloudiness and albedo conditions. In fact, the broad range of SZA values analyzed is only achieved when different seasons are covered (small SZA exclusively in summer, large SZA exclusively in winter); how different seasons are linked with different levels of WVC and cloudiness, this dependence must be minimized. For this goal, relative MBE and SD remove the effect of WVC seasonal variation, and the cloud cover bins helps to avoid the dependence on seasonal variation of cloudiness. In this sense, the absolute and relative MBE and SD were calculated at $5^{\circ} \mathrm{SZA}$ bins from $20^{\circ}$ to $75^{\circ}$ for $\mathrm{AF}=0$ (land) and $\mathrm{AF}=1$ (sea), and for three different sky conditions: cloudfree $(C F=0)$, cloudy $(C F>0.5)$ and all cases (All). Other authors (e.g., Antón et al., 2015) considered cloud-free conditions when $\mathrm{CF}<0.1$, but the amount of data of the present work is enough to only considered $\mathrm{CF}=0$ as cloud-free, in order to guaranty this condition. The obtained results together with the number of data used in the analysis are plotted in Fig. 3. Furthermore, the std(MBE) and std(SD) are included in the panels for the values calculated with $\mathrm{AF}=0$.

For those cases with SZA below $40^{\circ}$ under cloud-free conditions, the accuracy of GOME- 2 is high for AF $=0$, while GOME-2 clearly overestimates GPS measurements for AF $=1$. In contrast, for the same SZA interval but under cloudy conditions, GOME-2 strongly underestimates GPS for $\mathrm{AF}=0$, while the $\mathrm{MBE}$ is near zero for $\mathrm{AF}=1$. These results suggest that GOME-2 retrieval algorithm overestimates WVC data for surface conditions flagged as sea under cloud-free conditions. Regarding the precision given by SD values for SZA lower than $40^{\circ}$, GOME-2 is more precise in land and under cloud-free conditions, followed by cloudy conditions in land and cloud-free in sea (around $2.5 \mathrm{~mm}$; $10-15 \%)$

For those cases with SZA above $40^{\circ}$ (when number of cloudy data increases), the cloud-free and cloudy GOME-2 data increase the relative overestimation with increasing SZA (for land albedo flag). The MBE values closest to zero are found for sea flag cases under cloudy conditions, which is caused due to the balanced effects over the GOME-2 retrieval algorithm: cloudy cases reduce MBE while the "sea" cases increase it. This balanced effect is not recorded by the SD parameter, reporting values higher than $20 \%$ for those conditions.

The strong SZA dependence shown in this subsection causes a systematic seasonal dependence of GOME-GPS differences. The absolute and relative GOME-GPS differences of the water vapor monthly means (2007-2012) were averaged by zones and shown in Table 4. The absolute differences are usually lower than $10 \%$ in spring and summer months for all zones, showing an underestimation of GOME-2 in spring and an overestimation of GOME- 2 in the remaining months. NA zone shows the lowest differences in winter likely caused by the offset of SZA and CF effects. SW zone is the area that shows in general the highest differences in the summer months, indicating that GOME-2 retrieval provides worse monthly WVC values in this zone than in the remaining areas. The differences are negative for April and May in all zones, which indicates that GOME-2 underestimates GPS in these months, likely due to $\mathrm{CF}$ is high enough (see Fig. 2), which reduces MBE, and SZA starts to be lower in these months (reducing also MBE).

\subsubsection{Cloudiness dependence}

The previous subsection has shown that the agreement between WVC from GOME-2 and GPS critically depends on cloudiness conditions during satellite overpass. In order to evaluate this dependency, Table 5 shows the statistical parameters for cloud-free $(C F=0)$, partially cloudy $(0<\mathrm{CF} \leq 0.5)$, cloudy ( $\mathrm{CF}>0.5)$ and all cases (All). For the four study zones, the $\mathrm{MBE}_{\mathrm{z}}$ is positive (negative) under cloud-free (cloudy) conditions which is in accordance with the results shown in Fig. 3. Similar results were obtained by Antón et al. (2015) and by Kalakoski et al. (2014) using radiosounding data.

Table 5

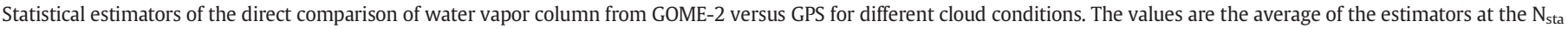
stations used in each zone, and the standard deviation of these averaged values is given in parentheses.

\begin{tabular}{|c|c|c|c|c|c|c|c|c|c|}
\hline Zone & Cloud condition & $\mathrm{N}$ & $\mathrm{N}_{\text {sta }}$ & $\mathrm{MBE}_{\mathrm{z}}(\mathrm{mm})$ & $\mathrm{MBE}_{\mathrm{z}}(\%)$ & $\mathrm{SD}_{\mathrm{z}}(\mathrm{mm})$ & $\mathrm{SD}_{\mathrm{z}}(\%)$ & $\overline{v_{z}\left(\Delta_{s}<\varepsilon\right)}(\%)$ & $\overline{v_{z}\left(\Delta_{s}<2 \varepsilon\right)}(\%)$ \\
\hline NA & $\mathrm{CF}=0$ & 686 & 3 & $3.0(0.5)$ & $21.7(2.2)$ & $2.8(0.4)$ & $21.3(1.5)$ & $56.5(8.7)$ & $95.7(1.4)$ \\
\hline NA & $0<\mathrm{CF} \leq 0.5$ & 1946 & 3 & $1.4(0.2)$ & $10.9(1.5)$ & $4.6(0.1)$ & $30.6(0.2)$ & $55.0(1.0)$ & $89.5(0.7)$ \\
\hline NA & $\mathrm{CF}>0.5$ & 1178 & 3 & $-1.4(0.1)$ & $-8.1(1.0)$ & $4.6(0.1)$ & $23.9(0.8)$ & $49.8(1.1)$ & $78.5(1.1)$ \\
\hline NA & All & 3810 & 3 & $0.8(0.2)$ & $6.9(1.9)$ & $4.6(0.2)$ & $29.2(0.8)$ & $53.8(1.6)$ & $87.2(1.3)$ \\
\hline C & $\mathrm{CF}=0$ & 3611 & 8 & $1.4(1.2)$ & $18.8(11.5)$ & $2.3(0.2)$ & $28.4(7.2)$ & $63.3(13.4)$ & $95.3(3.2)$ \\
\hline $\mathrm{C}$ & $0<\mathrm{CF} \leq 0.5$ & 4140 & 8 & $0.3(1.1)$ & $10.3(10.9)$ & $3.5(0.4)$ & $32.1(5.8)$ & $50.9(4.9)$ & $86.2(3.6)$ \\
\hline C & $\mathrm{CF}>0.5$ & 1493 & 8 & $-1.6(1.7)$ & $-5.6(11.3)$ & $3.7(0.4)$ & $28.6(4.4)$ & $45.1(9.1)$ & $75.1(10.2)$ \\
\hline $\mathrm{C}$ & All & 9244 & 8 & $0.4(1.2)$ & $11.0(11.1)$ & $3.3(0.4)$ & $31.4(5.7)$ & $54.8(6.7)$ & $88.0(2.7)$ \\
\hline M & $\mathrm{CF}=0$ & 2432 & 7 & $2.1(2.1)$ & $15.3(10.6)$ & $3.6(0.5)$ & $22.1(2.4)$ & $53.5(12.2)$ & $93.8(1.6)$ \\
\hline M & $0<\mathrm{CF} \leq 0.5$ & 4174 & 7 & $0.6(1.9)$ & $8.0(9.7)$ & $4.9(0.4)$ & $28.8(2.3)$ & $52.4(2.5)$ & $86.8(6.0)$ \\
\hline M & $\mathrm{CF}>0.5$ & 932 & 7 & $-2.8(1.6)$ & $-12.5(7.0)$ & $5.2(0.5)$ & $26.0(2.2)$ & $42.5(10.6)$ & $67.8(13.2)$ \\
\hline M & All & 7538 & 7 & $0.6(1.8)$ & $7.6(8.9)$ & $4.8(0.3)$ & $27.8(1.5)$ & $52.3(3.8)$ & $87.0(4.9)$ \\
\hline SW & $\mathrm{CF}=0$ & 1670 & 3 & $3.2(0.3)$ & $25.6(4.2)$ & $2.6(0.2)$ & $22.2(3.5)$ & $49.0(7.3)$ & $95.9(1.7)$ \\
\hline SW & $0<\mathrm{CF} \leq 0.5$ & 1175 & 3 & $1.3(0.4)$ & $12.8(2.4)$ & $4.4(0.2)$ & $29.8(4.8)$ & $48.9(1.9)$ & $88.3(3.7)$ \\
\hline SW & $\mathrm{CF}>0.5$ & 338 & 3 & $-2.9(1.3)$ & $-11.9(6.7)$ & $4.6(0.4)$ & $24.4(4.7)$ & $41.2(2.2)$ & $70.1(4.4)$ \\
\hline SW & All & 3183 & 3 & $1.9(0.2)$ & $17.1(3.4)$ & $4.0(0.2)$ & $28.0(3.5)$ & $48.0(4.2)$ & $90.5(2.0)$ \\
\hline All & $\mathrm{CF}=0$ & 8399 & 21 & $2.1(1.6)$ & $19.0(10.2)$ & $2.8(0.7)$ & $24.4(5.8)$ & $57.0(12.8)$ & $95.0(2.5)$ \\
\hline All & $0<\mathrm{CF} \leq 0.5$ & 11,435 & 21 & $0.7(1.4)$ & $10.0(9.0)$ & $4.3(0.7)$ & $30.5(4.5)$ & $51.7(3.9)$ & $87.2(4.5)$ \\
\hline All & $\mathrm{CF}>0.5$ & 3941 & 21 & $-2.1(1.6)$ & $-9.2(9.0)$ & $4.4(0.8)$ & 26.5 (3.9) & $44.3(8.8)$ & $72.5(10.8)$ \\
\hline All & All & 23,775 & 21 & $0.7(1.4)$ & $10.1(9.3)$ & $4.1(0.7)$ & $29.4(4.2)$ & $52.8(5.5)$ & $87.9(3.6)$ \\
\hline
\end{tabular}


Regarding $\mathrm{SD}_{z}$ values, they are similar for all zones, increasing from $20 \%$ with increasing CF. It must be noted that $\overline{v_{z}\left(\Delta_{S}<2 \varepsilon\right)}$ is around $95 \%$ for all zones when $\mathrm{CF}=0$, but not for the remaining cloud conditions. In fact, for $\mathrm{CF}=0, \overline{v_{z}\left(\Delta_{s}<2 \varepsilon\right)}$ is always around $95 \%$ and it presents no significant variation with location even when it is calculated (not shown) for the three SZA intervals analyzed in the previous subsection. This result indicates that all WVC differences between GOME-2 and GPS under cloud-free conditions can be explained by the error of GOME-2 WVC data, but not for cloudy conditions. The main reason behind this bad behavior of satellite WVC observations under cloudy conditions is the so-called shielding effect: clouds hide the water vapor below them (Kokhanovsky and Rozanov, 2008). GOME-2 algorithm removes from the retrieval those heavy cloudy scenes using the "H2O_flag", but does not make use of any cloud correction method for the remaining satellite scenes contaminated with some degree of cloudiness (Valks et al., 2011; Grossi et al., 2015). The estimators for partially cloudy conditions present similar values than for "All" conditions, which are between cloud-free and cloudy conditions. This result made that partially cloudy conditions were not included in the rest of this study since they are similar to "All" conditions.

In order to study the influence of SZA and AF on the CF dependency, Fig. 4 shows the MBE and SD as a function of $0.1 \mathrm{CF}$ bins for different SZA intervals, and for $\mathrm{AF}=0$ and $\mathrm{AF}=1$. The availability of data at each station decreases when CF increases. The relative SD shows the lowest values for low SZA values with land flag, being similar for all CF values. Regarding MBE, it is near to zero (good accuracy) for the smallest CF corresponding to $\mathrm{SZA}$ below $40^{\circ}$ with $\mathrm{AF}=0$. Additionally, all MBE curves show a sharp decrease with increasing $\mathrm{CF}$ up to $\mathrm{CF} \sim 0.3$, and from this value, a slight decrease or stabilization. Furthermore, it must be noted the large difference between the curves corresponding to "land" and "sea" surfaces for SZA values below $40^{\circ}$, with MBE close to zero for "sea" cases. This latter result is associated with a balanced effect between the satellite overestimation related to "sea" surfaces and the underestimation due to low SZA conditions.
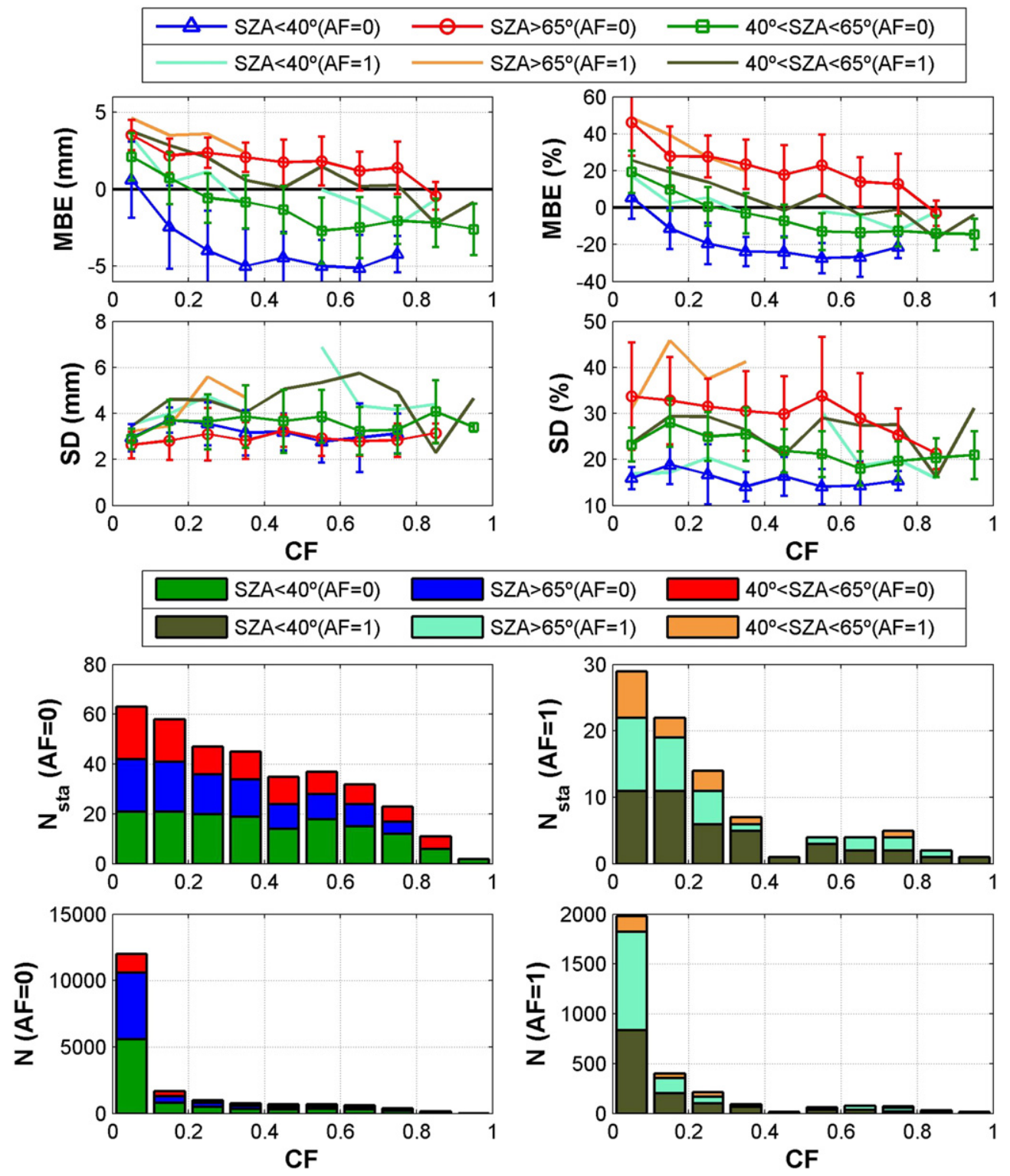

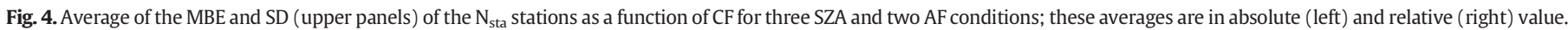

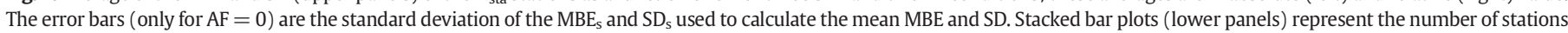

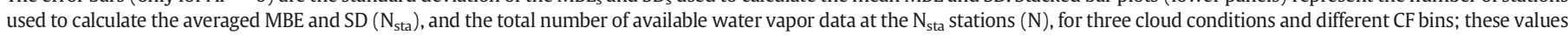
are represented for $\mathrm{AF}=0$ (left) and $\mathrm{AF}=1$ (right). 
Table 6

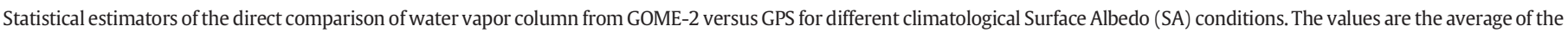
estimators at the $\mathrm{N}_{\text {sta }}$ stations used in each zone, and the standard deviation of these averaged values is given in parentheses.

\begin{tabular}{|c|c|c|c|c|c|c|c|c|c|}
\hline Zone & SA condition & $\mathrm{N}$ & $\mathrm{N}_{\text {sta }}$ & $\mathrm{MBE}_{\mathrm{z}}(\mathrm{mm})$ & $\mathrm{MBE}_{\mathrm{z}}(\%)$ & $\mathrm{SD}_{\mathrm{z}}(\mathrm{mm})$ & $\mathrm{SD}_{\mathrm{z}}(\%)$ & $\overline{v_{z}\left(\Delta_{s}<\varepsilon\right)}(\%)$ & $\overline{v_{z}\left(\Delta_{s}<2 \varepsilon\right)}$ \\
\hline NA & $\mathrm{SA} \leq 0.1$ & 2389 & 3 & $1.3(0.5)$ & $9.8(3.1)$ & $4.5(0.2)$ & $30.3(0.4)$ & $53.0(0.8)$ & $87.8(1.9)$ \\
\hline NA & $0.1<\mathrm{SA} \leq 0.2$ & 1325 & 3 & $-0.4(1.2)$ & $0.2(7.1)$ & $4.4(0.3)$ & $26.5(0.9)$ & $55.0(3.8)$ & $85.8(4.0)$ \\
\hline NA & $\mathrm{SA}>0.2$ & 96 & 3 & $-2.8(2.1)$ & $-11.3(7.9)$ & $4.6(0.5)$ & $22.2(1.5)$ & $43.3(14.0)$ & $67.8(14.9)$ \\
\hline $\mathrm{C}$ & $S A \leq 0.1$ & 129 & 3 & $3.4(0.9)$ & $40.4(12.6)$ & $3.2(0.2)$ & $50.8(17.9)$ & $47.7(8.1)$ & $88.5(8.8)$ \\
\hline C & $0.1<\mathrm{SA} \leq 0.2$ & 4990 & 8 & $1.1(1.2)$ & $18.9(14.6)$ & $2.9(0.4)$ & $31.8(6.0)$ & $54.3(9.9)$ & $90.8(3.17)$ \\
\hline C & $\mathrm{SA}>0.2$ & 4125 & 8 & $-0.6(1.4)$ & $-0.5(10.5)$ & $3.3(0.4)$ & $23.9(4.8)$ & $53.6(4.4)$ & $84.1(5.3)$ \\
\hline M & $\mathrm{SA} \leq 0.1$ & 6100 & 7 & $1.4(1.4)$ & $11.9(6.9)$ & $4.5(0.2)$ & $27.7(1.7)$ & $54.3(5.6)$ & $90.8(2.1)$ \\
\hline M & $0.1<\mathrm{SA} \leq 0.2$ & 1435 & 5 & $-3.5(1.6)$ & $-13.9(8.4)$ & $4.7(0.3)$ & $21.4(1.9)$ & $42.9(12.3)$ & $68.8(11.4)$ \\
\hline M & $S A>0.2$ & - & 0 & - & - & - & - & - & - \\
\hline SW & $S A \leq 0.1$ & 1065 & 2 & $1.6(0.2)$ & $14.0(0.1)$ & $4.3(0.4)$ & $25.7(2.6)$ & $50.6(2.2)$ & $91.4(2.4)$ \\
\hline SW & $0.1<\mathrm{SA} \leq 0.2$ & 1477 & 3 & $0.9(2.6)$ & $12.1(16.3)$ & $4.2(0.4)$ & $28.3(1.9)$ & $47.2(7.3)$ & $83.1(10.2)$ \\
\hline SW & $\mathrm{SA}>0.2$ & 640 & 2 & $-0.1(1.0)$ & $6.1(8.1)$ & $3.7(0.0)$ & $25.4(6.6)$ & $63.1(15.5)$ & $86.1(0.4)$ \\
\hline All & $\mathrm{SA} \leq 0.1$ & 9683 & 15 & $1.8(1.3)$ & $17.4(13.8)$ & $4.2(0.6)$ & $32.6(12.3)$ & $52.2(5.9)$ & $89.8(4.6)$ \\
\hline All & $0.1<\mathrm{SA} \leq 0.2$ & 9227 & 19 & $-0.4(2.5)$ & $6.2(18.6)$ & $3.8(0.9)$ & $27.7(5.9)$ & $50.3(10.9)$ & $83.0(11.7)$ \\
\hline All & $\mathrm{SA}>0.2$ & 4861 & 13 & $-1.0(1.8)$ & $-2.0(11.1)$ & $3.7(0.7)$ & $23.8(4.7)$ & $52.7(11.5)$ & $80.7(10.9)$ \\
\hline
\end{tabular}

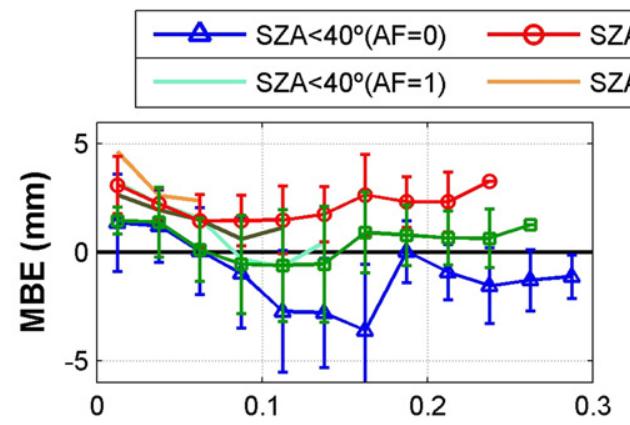

\begin{tabular}{|c|c|}
\hline $\mathrm{ZA}>65^{\circ}(\mathrm{AF}=0)$ & $\square-40^{\circ}<S Z A<65^{\circ}(A F=0)$ \\
\hline$Z A>65^{\circ}(A F=1)$ & $-40^{\circ}<\mathrm{SZA}<65^{\circ}(\mathrm{AF}=1)$ \\
\hline
\end{tabular}
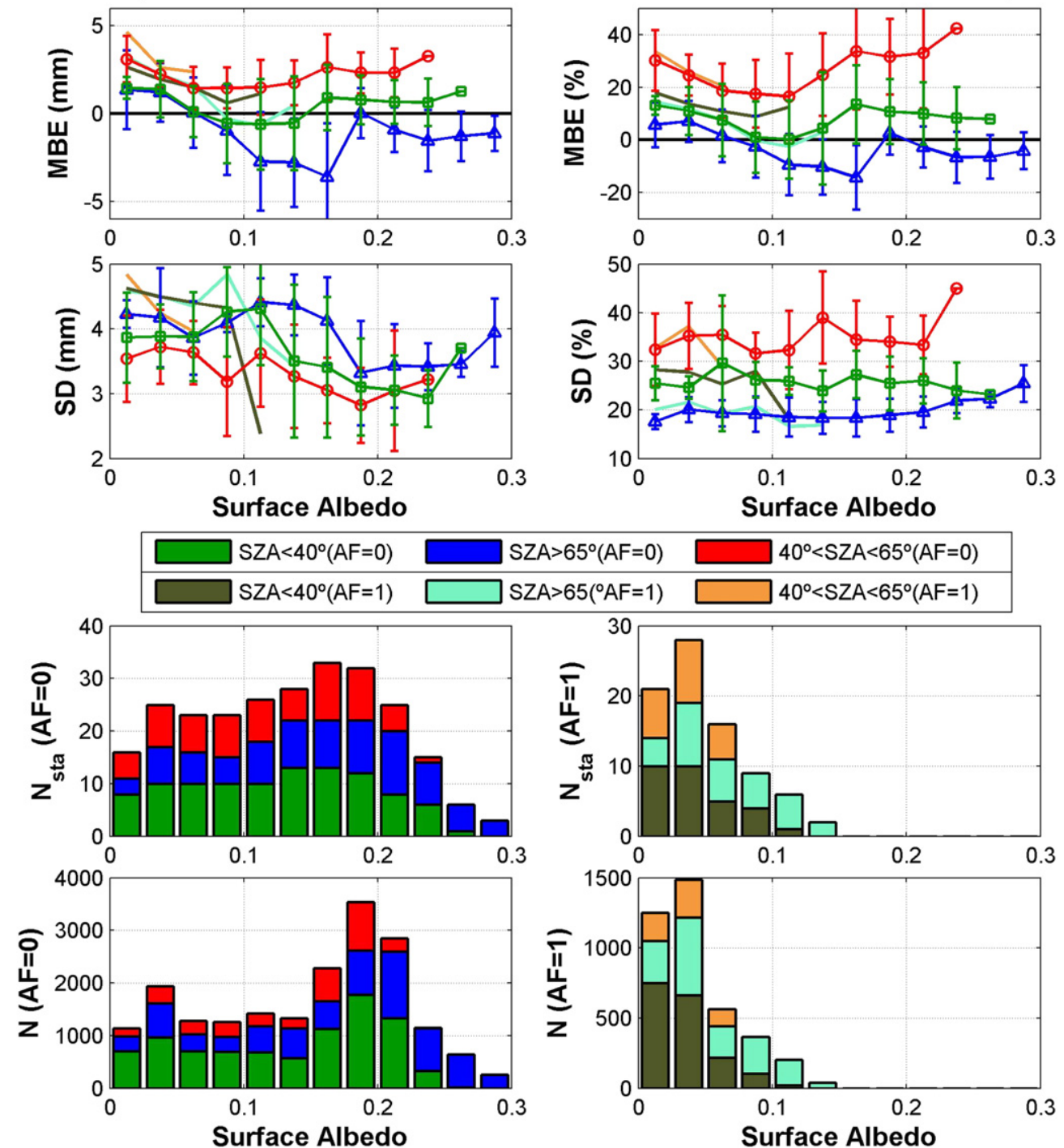

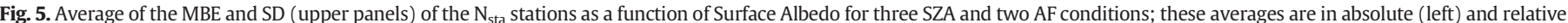

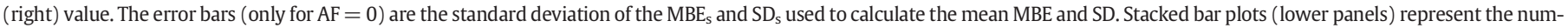

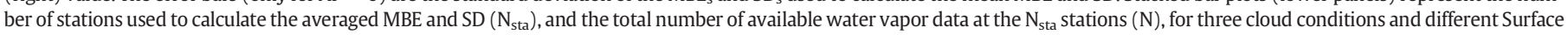
Albedo bins; these values are represented for $\mathrm{AF}=0$ (left) and $\mathrm{AF}=1$ (right). 


\subsubsection{Surface Albedo dependence}

In the previous two subsections the influence of SZA and CF on $\mathrm{MBE}_{\mathrm{z}}$ and $\mathrm{SD}_{\mathrm{z}}$ were studied considering two albedo flags: "land" and "sea". Here, the influence of ground reflectivity is evaluated using the Surface Albedo (SA) data. Table 6 shows the statistical parameters for different $\mathrm{SA}$ intervals. The best accuracy and precision $\left(\mathrm{MBE}_{\mathrm{z}} \sim 0\right.$ and low $\left.\mathrm{SD}_{\mathrm{z}}\right)$ is shown by NA zone for $0.1<\mathrm{SA} \leq 0.2$ and $\mathrm{C}$ zone for $\mathrm{SA}>0.2 . \mathrm{MBE}_{\mathrm{z}}$ usually decreases to values near to zero when SA increases, which likely is since stronger surface reflection should give a better WVC sensitivity. When all zones are analyzed together, the GOME-2 data overestimate the GPS measurements for SA $\leq 0.2$ and underestimates (with better precision) for the remaining Surface Albedos, which could be linked with the mentioned better WVC sensitivity under higher SA values. A similar result was found by Kalakoski et al. (2014) who found MBE values near to zero for Surface Albedo between 0.1 and 0.2 .

In order to minimize the possible effect of SZA, Fig. 5 shows the MBE and SD as a function of SA for three SZA intervals. The most of stations presents SA values between 0.15 and 0.20 (see Fig. 2), which causes that number of available data is higher in this range. Nevertheless, the results for low SA values are exclusively related to Mediterranean and North-Atlantic zones, while the results for higher albedos are mainly obtained in Continental data. As was found in the previous subsections, $\mathrm{MBE}$ and relative SD increase with increasing SZA. In addition, the precision of GOME-2 presents no significant variation with Surface Albedo. However, all MBE curves show a clear dependence on SA for values below 0.1, decreasing MBE values with increasing SA. These results suggest that GOME-2 data reduces the overestimation of GPS data for all SZA values when SA increases its value between 0 and 0.1 approximately. For the SA interval between 0.1 and 0.2 , the MBE values corresponding to low SZA value are more negative (increase of underestimation) with increasing SA, while the MBE values for medium and high SZA values are more positive (increase of overestimation) with increasing SA. For SA values above 0.2 , it can be seen a slight negative pattern of MBE values for all curves.

Fig. 6 displays the MBE and SD as a function of SA for different CF conditions. The dependence of MBE values on SA is completely in

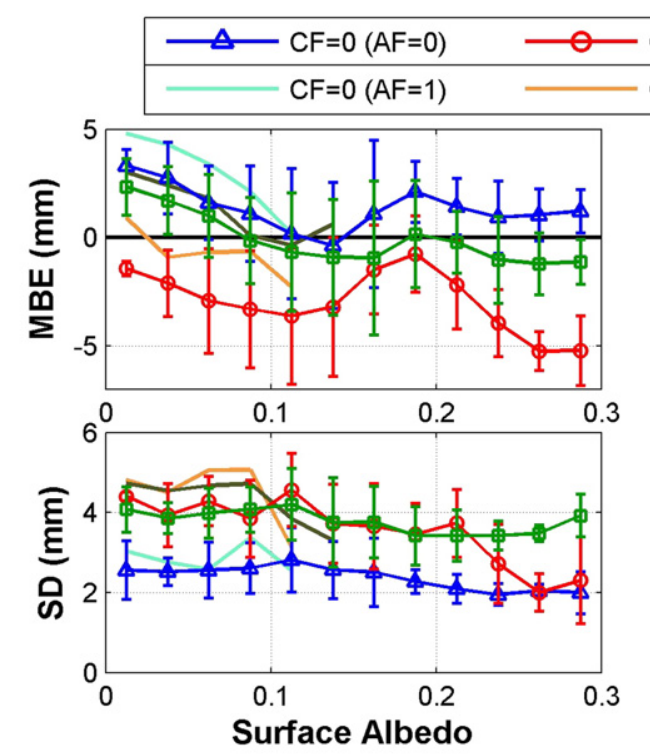

$\begin{array}{ll}C F>0.5(A F=0) & \because \text { All }(A F=0) \\ C F>0.5(A F=1) & \text { All }(A F=1)\end{array}$
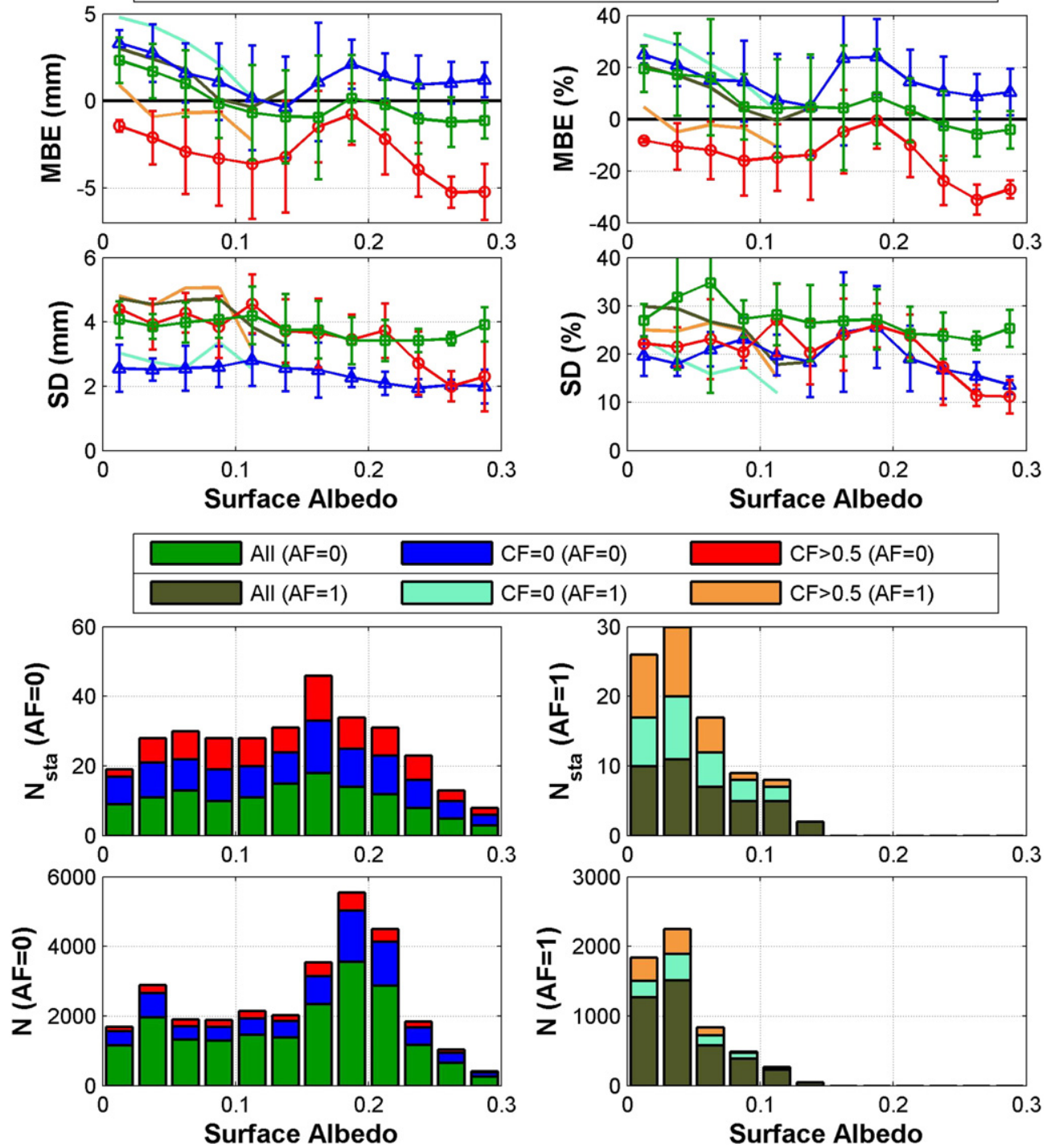

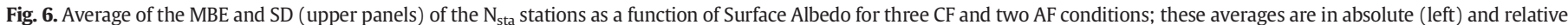

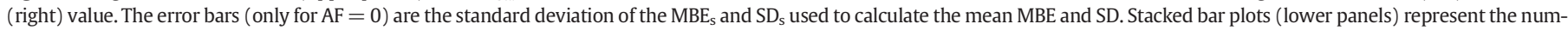

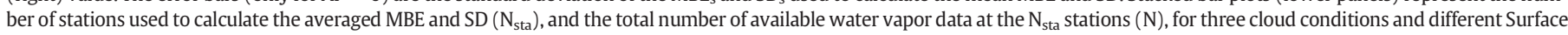
Albedo bins; these values are represented for $\mathrm{AF}=0$ (left) and $\mathrm{AF}=1$ (right). 
Table 7

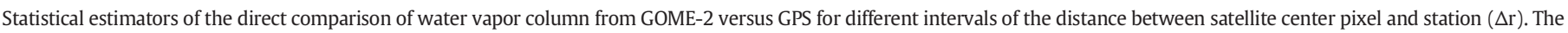
values are the average of the estimators at the $\mathrm{N}_{\mathrm{sta}}$ stations used in each zone, and the standard deviation of these averaged values is given in parentheses.

\begin{tabular}{|c|c|c|c|c|c|c|c|c|c|}
\hline Zone & $\Delta \mathrm{r}$ condition & $\mathrm{N}$ & $\mathrm{N}_{\text {sta }}$ & $\mathrm{MBE}_{\mathrm{z}}(\mathrm{mm})$ & $\mathrm{MBE}_{\mathrm{z}}(\%)$ & $\mathrm{SD}_{\mathrm{z}}(\mathrm{mm})$ & $\mathrm{SD}_{\mathrm{z}}(\%)$ & $\overline{v_{z}\left(\Delta_{s}<\varepsilon\right)}(\%)$ & $\overline{v_{z}\left(\Delta_{s}<2 \varepsilon\right)}(\%)$ \\
\hline NA & $\Delta \mathrm{r} \leq 20 \mathrm{~km}$ & 1110 & 3 & $0.8(0.5)$ & $5.5(2.9)$ & $4.4(0.2)$ & $25.9(0.6)$ & $54.1(1.1)$ & $87.7(2.9)$ \\
\hline NA & $\Delta \mathrm{r} \leq 40 \mathrm{~km}$ & 2435 & 3 & $0.9(0.4)$ & $6.1(2.2)$ & $4.4(0.1)$ & $26.7(1.0)$ & $54.6(0.2)$ & $87.9(1.7)$ \\
\hline NA & $\Delta \mathrm{r} \leq 60 \mathrm{~km}$ & 3112 & 3 & $0.9(0.4)$ & $6.6(2.2)$ & $4.5(0.2)$ & $27.7(1.8)$ & $54.3(1.8)$ & $87.6(1.4)$ \\
\hline NA & $\Delta \mathrm{r} \leq 80 \mathrm{~km}$ & 3534 & 3 & $0.8(0.3)$ & $6.8(2.2)$ & $4.6(0.2)$ & $28.9(1.3)$ & $53.8(2.2)$ & $87.1(1.9)$ \\
\hline C & $\Delta \mathrm{r} \leq 20 \mathrm{~km}$ & 3025 & 8 & $0.4(1.2)$ & 9.5 (10.9) & $2.8(0.4)$ & $26.2(5.1)$ & $59.3(10.1)$ & $90.5(2.4)$ \\
\hline C & $\Delta \mathrm{r} \leq 40 \mathrm{~km}$ & 6681 & 8 & $0.5(1.2)$ & $10.5(11.4)$ & $2.9(0.4)$ & $27.7(4.6)$ & $57.7(9.3)$ & $90.0(3.0)$ \\
\hline C & $\Delta \mathrm{r} \leq 60 \mathrm{~km}$ & 7860 & 8 & $0.4(1.2)$ & $10.5(11.7)$ & $3.1(0.4)$ & $29.1(5.1)$ & $56.6(8.6)$ & $89.2(3.0)$ \\
\hline C & $\Delta \mathrm{r} \leq 80 \mathrm{~km}$ & 8596 & 8 & $0.4(1.2)$ & $10.6(11.7)$ & $3.2(0.4)$ & $30.2(5.4)$ & $55.8(7.8)$ & $88.4(2.9)$ \\
\hline M & $\Delta \mathrm{r} \leq 20 \mathrm{~km}$ & 2763 & 7 & $0.9(1.8)$ & $8.8(8.5)$ & $3.9(0.3)$ & $23.2(2.7)$ & $58.4(9.0)$ & $92.2(2.4)$ \\
\hline M & $\Delta \mathrm{r} \leq 40 \mathrm{~km}$ & 5374 & 7 & $0.7(1.9)$ & $7.9(9.3)$ & $4.3(0.3)$ & $25.0(2.2)$ & $54.8(5.7)$ & $89.4(4.1)$ \\
\hline M & $\Delta \mathrm{r} \leq 60 \mathrm{~km}$ & 6296 & 7 & $0.7(2.0)$ & $7.9(9.8)$ & $4.4(0.3)$ & $26.1(2.0)$ & $54.2(5.4)$ & $88.7(4.6)$ \\
\hline M & $\Delta \mathrm{r} \leq 80 \mathrm{~km}$ & 6966 & 7 & $0.6(1.9)$ & $7.8(9.6)$ & $4.7(0.3)$ & $27.1(1.6)$ & $53.0(4.7)$ & $87.7(5.1)$ \\
\hline SW & $\Delta \mathrm{r} \leq 20 \mathrm{~km}$ & 1321 & 3 & $2.8(0.3)$ & $22.4(4.7)$ & $3.7(0.2)$ & $27.6(4.3)$ & $43.4(7.0)$ & $92.3(3.6)$ \\
\hline SW & $\Delta \mathrm{r} \leq 40 \mathrm{~km}$ & 2512 & 3 & $2.2(0.3)$ & $18.8(4.2)$ & $3.7(0.1)$ & $26.6(4.3)$ & $48.3(6.0)$ & $92.2(2.9)$ \\
\hline SW & $\Delta \mathrm{r} \leq 60 \mathrm{~km}$ & 2751 & 3 & $2.0(0.3)$ & $17.5(4.3)$ & $3.8(0.2)$ & $27.0(4.2)$ & $48.6(5.5)$ & $91.7(2.5)$ \\
\hline SW & $\Delta \mathrm{r} \leq 80 \mathrm{~km}$ & 3004 & 3 & $2.0(0.3)$ & $17.4(4.6)$ & $4.0(0.2)$ & $27.7(4.3)$ & $48.0(5.2)$ & $90.9(2.5)$ \\
\hline All & $\Delta \mathrm{r} \leq 20 \mathrm{~km}$ & 8219 & 21 & $1.0(1.5)$ & $10.5(9.7)$ & $3.5(0.7)$ & $25.4(4.0)$ & $56.0(9.8)$ & 90.9 (2.9) \\
\hline All & $\Delta \mathrm{r} \leq 40 \mathrm{~km}$ & 17,002 & 21 & $0.9(1.4)$ & $10.2(9.4)$ & $3.7(0.7)$ & $26.5(3.5)$ & $54.9(7.3)$ & $89.8(3.3)$ \\
\hline All & $\Delta \mathrm{r} \leq 60 \mathrm{~km}$ & 20,019 & 21 & $0.8(1.4)$ & $10.1(9.5)$ & $3.8(0.7)$ & $27.6(3.7)$ & $54.3(6.7)$ & $89.1(3.4)$ \\
\hline All & $\Delta \mathrm{r} \leq 80 \mathrm{~km}$ & 22,100 & 21 & $0.8(1.4)$ & $10.1(9.5)$ & $4.0(0.7)$ & $28.6(3.9)$ & $53.5(6.1)$ & $88.3(3.6)$ \\
\hline
\end{tabular}

accordance with the results shown in Fig. 5. Thus, MBE values decrease on increasing SA for the ranges $0-0.1$ and $0.2-0.3$, but they rise between 0.1 and 0.2 for cloud-free and cloudy conditions. This change in the behavior of SA dependency for the interval 0.1-0.2 was also shown by Kalakoski et al. (2014) (see their Fig. 6, right). Overall, the variation of MBE and SD with Surface Albedo is weaker than the variation caused by SZA and CF.

\subsubsection{Distance between station and pixel center}

The results of this paper have been obtained considering that GOME2 data correspond with the GPS data at stations even if the satellite pixel center is $100 \mathrm{~km}$ far from the stations. However, the distance between the pixel center and the station could affect the agreement between GPS and GOME-2 data. In order to study the effect of this distance on the agreement, some statistical parameters for different distance intervals were calculated and showed in Table $7.35 \%, 72 \%$ and $85 \%$ of all available data are within $20 \mathrm{~km}, 40 \mathrm{~km}$ and $60 \mathrm{~km}$, respectively; it means that the obtained results are much influenced by the shortest distances. Relative $\mathrm{MBE}_{\mathrm{z}}$ decreases when the threshold of maximum $\Delta \mathrm{r}$ increases in NA and $\mathrm{C}$ zones, but it decreases in $\mathrm{M}$ and $\mathrm{SW}$ zones. $\mathrm{MBE}_{\mathrm{z}}$ variations with $\Delta \mathrm{r}$ are not much high since they range from $10.5 \%(\Delta \mathrm{r} \leq 20 \mathrm{~km})$ to $10.1 \%(\Delta \mathrm{r} \leq 100 \mathrm{~km})$ for all stations together. On the other hand, the precision is worse when $\Delta \mathrm{r}$ up to $100 \mathrm{~km}$ is considered because $\mathrm{SD}_{z}$ increase in all zones, being from $25.4 \%(\Delta \mathrm{r} \leq 20 \mathrm{~km})$ to $29.4 \%(\Delta \mathrm{r} \leq 100 \mathrm{~km})$ when all stations are taken into account. Similar case happens with the values of $\overline{v_{z}\left(\Delta_{s}<\varepsilon\right)}$ and $\overline{v_{z}\left(\Delta_{s}<2 \varepsilon\right)}$, which slightly decrease when $\Delta \mathrm{r}$ increases. These results point out that accuracy does not depends much on $\Delta r$ likely because the differences are compensated, but the precision is sensible to $\Delta r$, showing more variation of the differences between GPS and GOME-2 data when $\Delta \mathrm{r}$ increases.

\section{Conclusions}

The water vapor column retrieved by GOME-2 on board MetOp-A platform is very promising, being in a good agreement with the GPS data recorded at the Iberian Peninsula. Nevertheless, this satellite product still needs some improvements in order to reduce the notable geometrical dependence observed for SZA above $40^{\circ}$.

Water vapor column retrieved by GOME- 2 presents significant differences when is compared against GPS data at the Iberian Peninsula. The accuracy and precision of GOME- 2 to predict WVC depend strongly on SZA and the cloud fraction, presenting better precision for SZA values below $40^{\circ}$ and cloud-free conditions. In fact, the differences between GOME-2 and GPS data are within the GOME-2 error for cloud-free conditions. The effect of SZA and CF on the differences between GOME-2 and GPS is the main responsible of the differences between the calculated WVC monthly averages from GOME-2 and GPS; these differences being usually lower than $10 \%$ in spring and summer months for all zones mainly due to the low CF and SZA reached in these seasons.

The accuracy and precision of GOME-2 depend also, but weaker, on the type of surface (land or sea) and its albedo. GOME-2 is more precise under land and sea cloud-free, while the accuracy is better for land cloud-free under low SZA values and worse for sea and land cloudy when SZA increases. Regarding Surface Albedo value, MBE usually decreases to values near to zero when SA increases. All these results are obtained using data which distance between satellite pixel and station is lower than $100 \mathrm{~km}$, then the data with highest distances could be responsible in part of a worse precision, although the major part of data present a distance lower than $40 \mathrm{~km}$.

\section{Acknowledgments}

The GOME-2/MetOp-A products were generated at DLR under the auspices of the O3MSAF project funded by EUMETSAT and national contributions. The ZTD measurements used in this study have been provided by the Spanish Geographic Institute (IGN), and the temperature and pressure measurements by the Spanish Meteorological Agency (AEMet). Financial support to the University of Valladolid was provided by European Union (ACTRIS-2 project), the Spanish MINECO (Ref. Projects CGL2011-23413 and CGL2012-33576) and by “Junta de Castilla y León" (AERQUA Ref. Project VA100U14). This work was also supported by MINECO through project CGL2011-29921-C02 and CGL201456255-C2-1-R. Manuel Antón thanks "Ministerio de Ciencia e Innovación" and "Fondo Social Europeo" for the award of a postdoctoral grant (Ramón y Cajal).

\section{References}

Antón, M., Loyola, D., Román, R., Vömel, H., 2015. Validation of GOME-2/MetOp-A total water vapour column using reference radiosonde data from GRUAN network. Atmos. Meas. Tech. 8, 1135-1145. http://dx.doi.org/10.5194/amt8-1135-2015.

Baker, H.C., Dodson, A.H., Penna, N.T., Higgins, M., Offiler, D., 2001. Ground-based GPS water vapour estimation: potential for meteorological forecasting. J. Atmos. Sol. Terr. Phys. 63, 1305-1314.

Bennouna, Y.S., Torres, B., Cachorro, V.E., de Galisteo JP, Ortiz, Toledano, C., 2013. The evaluation of the integrated water vapour annual cycle over the Iberian Peninsula 
from EOS-MODIS against different ground-based techniques. Q. J. R. Meteorol. Soc. 139, 1935-1956. http://dx.doi.org/10.1002/qj.2080.

Bevis, M., Businger, S., Herring, T.A., Rocken, C., Anthes, R.A., Ware, R.H., 1992. GPS meteorology: remote sensing of atmospheric water vapor using the global positioning system. J. Geophys. Res. 97, 15787-15801.

Bovensmann, H., Burrows, J.P., Buchwitz, M., Frerick, J., Noël, S., Rozanov, V.V., et al., 1999. SCIAMACHY - mission objectives and measurement modes. J. Atmos. Sci. 56, 127-150. http://dx doi.org/10.1175/1520-0469(1999)056<0127:SMOAMM >2.0.CO.

Burrows, J., Weber, M., Buchwitz, M., Rozanov, V.V., Ladstädter-Weissenmayer, A., Richter, A., et al., 1999. The Global Ozone Monitoring Experiment (GOME): mission concept and first scientific results. J. Atmos. Sci. 56, 151-175.

Cachorro, V.E., de Frutos, A.M., Casanova, J.L., 1987. Absorption by oxygen and water vapor in the real atmosphere. Appl. Opt. 26, 501-505.

Cachorro, V.E., Utrillas, P., Durán, P., Vergáz, R., de Frutos, A., Martínez-Lozano, J.A., 1998. An study about the water vapor content determination in the $940 \mathrm{~nm}$ band by using moderated spectral resolution measurements of direct solar irradiance. Appl. Opt. 37, 4678-4689.

Colman, R., 2003. A comparison of climate feedbacks in GCMs. Clim. Dyn. 20, 865-873.

Duan, J., Bevis, M., Fang, P., Bock, Y., Chiswell, S., Businger, S., et al., 1996. GPS meteorology: direct estimation of the absolute value of precipitable water. J. Appl. Meteorol. 35, $830-838$.

Durre, I., Junior, C.N.W., Yin, X., Vose, R.S., 2009. Radiosonde-based trends in precipitable water over the Northern Hemisphere: an update. J. Geophys. Res. 114, D05112. http://dx.doi.org/10.1029/2008JD010989.

EUMETSAT, 2011. European Organisation for the Exploitation of Meteorological Satellites: GOME-2 Product Guide. Ref.: EUM/OPS-EPS/MAN/07/0445 (Issue: v3, Date: 17 Mar 2011).

Grossi, M., Kalakoski, N., Valks, P., 2013. O3M SAF ORR Validation Report, SAF/O3M/DLR/ ORR/H2O (Issue 01/2013).

Grossi, M., Valks, P., Loyola, D., Aberle, B., Slijkhuis, S., Wagner, T., et al., 2015. Total column water vapour measurements from GOME-2 MetOp-A and MetOp-B. Atmos. Meas. Tech. 8, 1111-1133. http://dx.doi.org/10.5194/amt-8-1111-2015.

Herring, T., Davis, J.L., Shapiro, I.I., 1990. Geodesy by radio interferometry: the application of Kalman filtering to the analysis of very long baseline interferometry data. J. Geophys. Res. 95, 12561-12581.

Hogg, D.C., Guiraud, F., Decker, M., 1981. Measurements of excess transmission length on earth-space path. Astron. Astrophys. 95, 304-307.

IPCC (Intergovernmental Panel on Climate Change), 2013. Climate Change 2013: The physical science basis. In: Stocker, T.F., Qin, D. (Eds.), Cambridge University Press, Cambridge, UK and New York, p. 1535.

Kalakoski, N., Wagner, T., Mies, K., Beirle, S., Slijkhuis, S., Loyola, D., 2011. O3M SAF Validation Report. Offline Total Water Vapour (SAF/O3M/FMI/VR/H2O/111).

Kalakoski, N., Kujanpää, J., Sofieva, V., Tamminen, J., Grossi, M., Valks, P., 2014. Comparison of GOME-2/Metop total column water vapour with ground-based and in situ measurements. Atmos. Meas. Tech. Discuss. 7, 12517-12543. http://dx.doi.org/10. 5194/amtd-7-12517-2014.

Kaufman, Y., Gao, B., 1992. Remote sensing of water vapour in the near IR from EOS/ MODIS. IEEE Trans. Geosci. Remote Sens. 30, 871-884.

Kiehl, J., Trenberth, K., 1997. Earth's annual global mean energy budget. Bull. Am. Meteorol. Soc. 78, 197-208.

Kokhanovsky, A.A., Rozanov, V.V., 2008. The uncertainties of satellite DOAS total ozone retrieval for a cloudy sky. Atmos. Res. 87, 27-36. http://dx.doi.org/10.1016/j.atmosres. 2007.04.006

Li, Z., Muller, J.-P., Cross, P., 2003. Comparison of precipitable water vapor derived from radiosonde, GPS, and Moderate-Resolution Imaging Spectroradiometer measurements. J. Geophys. Res. 108, D204651. http://dx.doi.org/10.1029/2003JD003372.

Lindstrot, R., Preusker, R., Diedrich, H., Doppler, L., Bennartz, R., Fischer, J., 2012. 1D-Var retrieval of daytime total columnar water vapour from MERIS measurements. Atmos. Meas. Tech. 5, 631-646. http://dx.doi.org/10.5194/amt-5-631-2012.

Livingston, J.M., Schmid, B., Redemann, J., Russell, P.B., Ramirez, S.A., Eilers, J., 2007. Comparison of water vapor measurements by airborne sunphotometer and nearcoincident in situ and satellite sensors during INTEX/ITCT 2004. J. Geophys. Res. 112, D12S16. http://dx.doi.org/10.1029/2006JD007733.

Loyola, D., Zimmer, W., Kiemle, S., Valks, P., Pedergnana, M., 2012. Product User Manual for GOME Total Columns of Ozone, NO2, tropospheric NO2, BrO, SO2, H2O, HCHO, OClO, and Cloud Properties. DLR/GOME/PUM/01 (Iss./Rev. 2E).
McMillin, L.M., Zhao, J., Rama Varma Raja, M.K., Gutman, S.I., Yoe, J.G., 2007. Radiosonde humidity corrections and potential Atmospheric Infrared Sounder moisture accuracy. J. Geophys. Res. 112, D13S90. http://dx.doi.org/10.1029/2005JD006109.

Mears, C.A., Wang, J., Smith, D., Wentz, F.J., 2015. Intercomparison of total precipitable water measurements made by satellite-borne microwave radiometers and groundbased GPS instruments. J. Geophys. Res. 120, 2492-2504. http://dx.doi.org/10.1002/ 2014JD022694.

Mieruch, S., Noël, S., Bovensmann, H., Burrows, J.P., 2006. Verification of SCCIAMCHY Level 1 Data by AMC-DOAS Water Vapour Retrieval. Proceedings of the Third Workshop on the Atmospheric Chemistry Validation of ENVISAT (ACVE-3) (4-7 Dec. 2006, ESA/ ESRIN, Frascati, Italy, ESA Publications Division Special Publication SP-642 (CD).

Munro, R., Eisinger, M., Anderson, C., Callies, J., Corpaccioli, E., Lang, R., et al., 2006. GOME-2 on MetOp: From In-orbit Verification to Routine Operations. Proceedings of EUMETSAT Meteorological Satellite Conference, Helsinki (Finland, 12-16 June 2006)

Noël, S, Mieruch, S., Buchwitx, M., Bovensmann, H., Burrows, J.P. 2006. GOME and SCIAMACHY Global Water Vapour Columns. Proc of the First 'Atmospheric Science Conference'. ESRIN, Frascati, Italy (8-12 May 2006).

Noël, S., Mieruch, S., Bovensmann, H., Burrows, J.P., 2008. Preliminary results of GOME-2 water vapour retrievals and first applications in polar regions. Atmos. Chem. Phys. 8, 1519-1529. http://dx.doi.org/10.5194/acp-8-1519-2008.

Ortiz de Galisteo, J.P., Cachorro, V., Toledano, C., Torres, B., Laulainen, N., Bennouna, Y., et al., 2011. Diurnal cycle of precipitable water vapor over Spain. Q. J. R. Meteorol. Soc. 137, 948-958.

Ortiz de Galisteo, J.P., Bennouna, Y., Toledano, C., Cachorro, V., Romero, P., Andrés, M.I., et al., 2014. Analysis of the annual cycle of the precipitable water vapour over Spain from 10-year homogenized series of GPS data. Q. J. R. Meteorol. Soc. 140, 397-406. http://dx.doi.org/10.1002/qj.2146.

Pérez-Ramírez, D., Whiteman, D.N., Smirnov, A., Lyamani, H., Holben, B.H., Pinker, R., et al., 2014. Evaluation of AERONET precipitable water vapor versus microwave radiometry, GPS, and radiosondes at ARM sites. J. Geophys. Res. 119 (15), 9596-9613. http://dx. doi.org/10.1002/2014JD021730.

Ray, R.D., Ponte, R.M., 2003. Barometric tides from ECMWF operational analyses. Ann. Geophys. 21, 1897-1910. http://dx.doi.org/10.5194/angeo-21-1897-2003.

Resch, G.M., 1984. Water Vapor Radiometry in Geodetic Applications. In: Brunner, F.K. (Ed.), Geodetic Refraction. Springer-Verlag, New York, pp. 53-84.

Román, R., Bilbao, J., de Miguel, A., 2014a. Solar radiation simulations in the Iberian Peninsula: accuracy and sensitivity to uncertainties in inputs of a radiative transfer model. J. Quant. Spectrosc. Radiat. 145, 95-109. http://dx.doi.org/10.1016/j.jqsrt. 2014.04.028.

Román, R., Bilbao, J., de Miguel, A., 2014b. Uncertainty and variability in satellite-based water vapor column, aerosol optical depth and Angström Exponent, and its effect on radiative transfer simulations in the Iberian Peninsula. Atmos. Environ. 89 556-569.

Ross, R.J., Elliott, W.P., 2001. Radiosonde-based Northern Hemisphere tropospheric water vapor trends. J. Clim. 14, 1602-1611.

Schneider, M., Romero, P.M., Hase, F., Blumenstock, T., Cuevas, E., Ramos, R., 2010. Continuous quality assessment of atmospheric water vapour measurement techniques: FTIR, Cimel, MFRSR, GPS, and Vaisala RS92. Atmos. Meas. Tech. 3, 323-338. http:// dx.doi.org/10.5194/amt-3-323-2010.

Soden, B.J., Held, I.M., 2006. An assessment of climate feedbacks in coupled oceanatmosphere models. J. Clim. 19, 3354-3360. http://dx.doi.org/10.1175/JCLI3799.1.

Torres, B., Cachorro, V., Toledano, C., de Galisteo JP, Ortiz, Berjón, A., de Frutos, A., et al., 2010. Precipitable water vapour characterization in the Gulf of Cadiz region (southwestern Spain) based on sunphotometer, GPS, and radiosonde data. J. Geophys. Res. 115, D18103.

Tralli, D.M., Lichten, S.M., 1990. Stochastic estimation of tropospheric path delays in global positioning system geodetic measurements. Bull. Géod. 64, 127-159.

Valks, P., Loyola, D., Hao, N., Rix, M., Slijkhuis, S., 2011. Algorithm Theoretical Basis Document for GOME-2 Total Column Products of Ozone, Minor Trace Gases and Cloud Properties (GDP 4.5 for O3M-SAF OTO and NTO), DLR/GOME-2/ATBD/01. (Iss./Rev.: 2/E, available at: http://atmos.eoc.dlr.de/gome2/docs/DLR_GOME-2 ATBD.pdf (last access: 1 February 2015).

Wentz, F.J., 2013. SSM/I Version-7 Calibration Report. Report number 011012. Remote Sensing Systems, Santa Rosa, CA (46 pp.). 